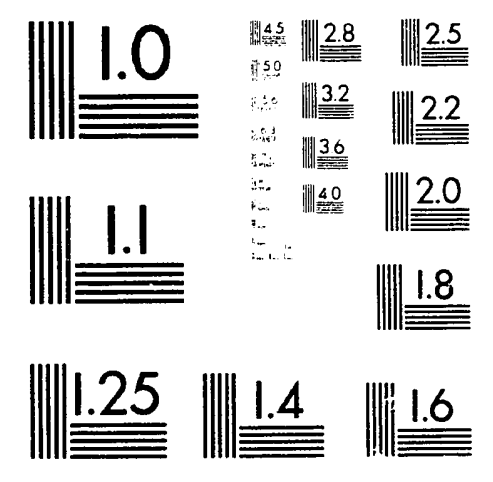



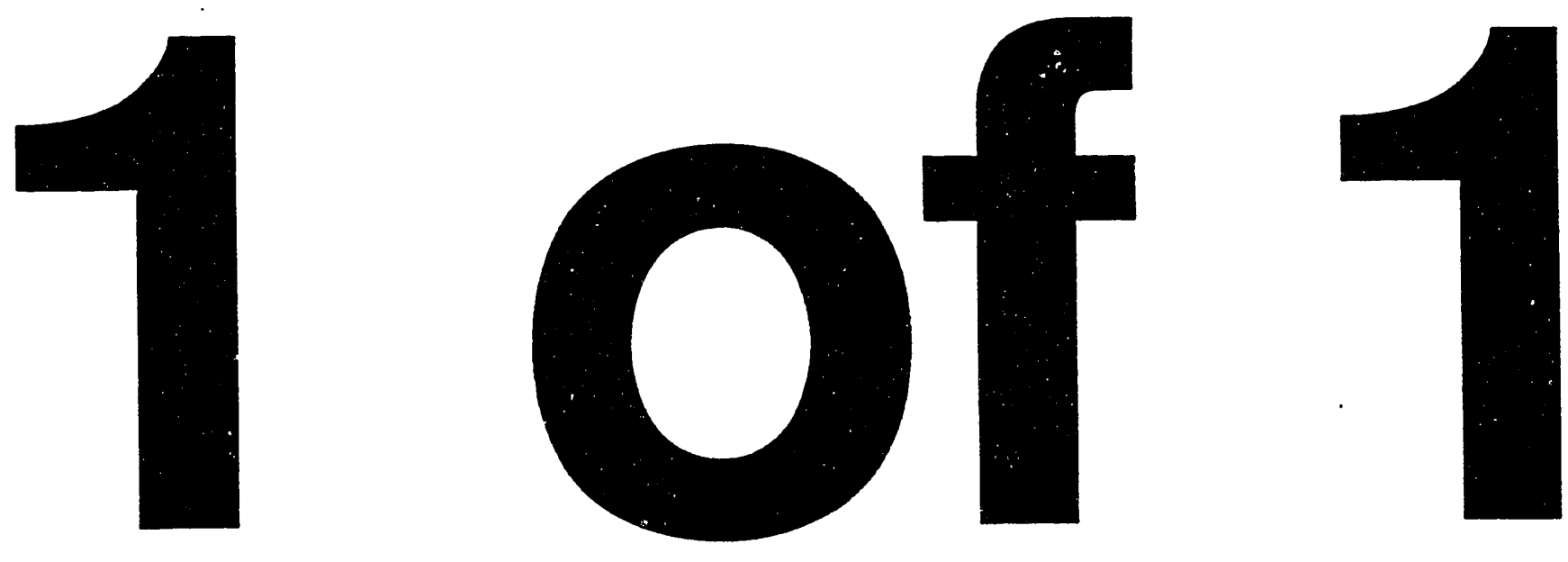


\title{
CONTINUOUS REDUCTION OF URANIUM TETRAFLUORIDE
}

\author{
A. L. DeMint \\ A. W. Maxey
}

Prepared by the

Oak Ridge Y-12 Plant

P.O. Box 2009, Oak Ridge, Tennessee 37831-8169

managed by

MARTIN MARIETTA ENERGY SYSTEMS, INC.

for the

U.S. DEPARTMENT OF ENERGY

under contract DE-AC05-84OR21400 
LIST OF FIGURES $\ldots \ldots \ldots \ldots \ldots \ldots \ldots \ldots \ldots \ldots \ldots \ldots \ldots \ldots \ldots \ldots \ldots$

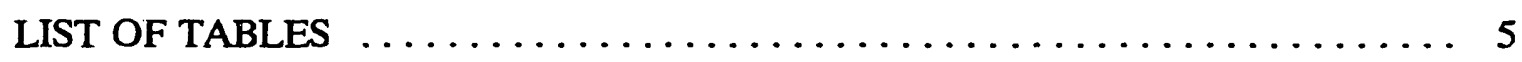

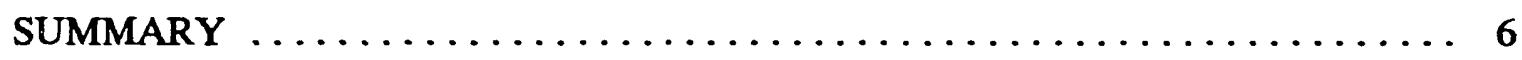

INTRODUCTION $\ldots \ldots \ldots \ldots \ldots \ldots \ldots \ldots \ldots \ldots \ldots \ldots \ldots \ldots$

PRIOR WORK $\ldots \ldots \ldots \ldots \ldots \ldots \ldots \ldots \ldots \ldots \ldots \ldots \ldots \ldots \ldots$

PRESENTATION OF EXPERIMENTAL WORK ............... 9

FUTURE WORK $\ldots \ldots \ldots \ldots \ldots \ldots \ldots \ldots \ldots \ldots \ldots \ldots \ldots \ldots \ldots$ 


\section{LIST OF FIGURES}

Figure

Page

1 Setup for Runs 3, 4, and 5. (a) Overall view of the furnace and feeder; (b) detail of feeder; (c) detail of reactor setup; and (d) cutaway drawing of reactor.

2 Feed valve ball.

3 Sintered feed clogging the feed tube. The outer channel is a vent.

4 End of crust breaker, with feed material sintered on end.

5 Magnesium layer on top, salt with magnesium droplets, and uranium button at bottom.

6 Product from Run 3. At left, top of uranium button; at right, bottom of salt layer.

$7 \quad$ Macrograph of impure salt. 21

8 Macrograph of a polished fragment of salt from Run 3. The black circles are uranium, and the gray magnesium that encircles the droplets can be seen on some.

9 Macrograph of a uranium droplet found suspended in the salt.

10 One of the magnesium-coated uranium alloy droplets. (50X) 22

11 Backscattered electron image of a uranium droplet. The white 23 grains are alpha-uranium; they are surrounded by $\mathrm{FeU}_{6}$. The dark areas are a 2-phase mixture of $\mathrm{FeU}_{6}$ and $\mathrm{Fe}_{2} \mathrm{U}$. (800X)

12 Reactor and susceptor from Run 4. The hole in the center is where the crust breaker rod was inserted at the end of the run. High oxygen levels in the furnace caused an orange uranium oxide coating.

13 Fixturing and product from Run 4. At left, bottom of graphite susceptor filled with uranium alloy and salt; middle, by-product salt with the lower portion of the alumina crucible broken away; right, bottom of alumina crucible with hole where the crust breaker pierced it.

14 Uranium alloy in the bottom of the graphite susceptor.

15 Uranium alloy adhering to the bottom of the graphite susceptor.

The graphite would not break free from the uranium, but instead broke into smaller pieces of graphite and uranium.

16 From Run 4, crust is at left and the magnesium and salt layers are at right.

17 Below the protective covering of unreacted feed, the magnesium pool was bright and shiny. 
18 Gray, poorly separated magnesium fluoride-sodium chloride salt. Trie wires running through the salt are thermocouples, originally protected in an alumina tube.

19 Bottom of the feed tube-no feed buildup this time. The wire tied to one side is a thermocouple.

20 Impure salt from Run 4. Not allowed sufficient time at temperature for settling to occur, the salt is riddled with droplets of metal.

21 Run 5 shows alumina vessel with layer of green unreacted feed on top.

22 Products from Run 5: magnesium layer on top, white and gray salt layers, and uranium alloy button on bottom.

23 Cross section of the gray, impure salt layer at the bottom showing some droplets of metal and thin layers of impurities. The gray color is apparently caused by small amounts of uranium or $\mathrm{UO}_{2}$.

$24 \quad$ Uranium alloy button from Run 5.

25 Scale drawing of the reactor setup and products formed in Run 5. 37

26 Casting 1 with hot top removed. 38

$27 \quad$ Fracture surface of Casting 1. 39

28 Uranium alloy spattered on the fiber insulator sleeve and lid used in $\quad 40$ Casting 1. (a) Sleeve; (b) lid. 


\section{LIST OF TABLES}

\section{Table}

1 Weight percent of feed material used for these experiments

2 Weights (in grams) of precharged material and product in Runs 3, 4, and 5

3 Constituents of the various layers in the Run 4 reactor as determined by $\mathrm{X}$-ray diffractions

4 Average concentraticas of uranium, iron, and magnesium in the uranium alloy created in Runs 3 and 4

Selected impurities and their levels found in the uranium alloy from Run 3 


\section{SUMMARY}

Operation of a pilot-scale system for continuous metallothermic reduction of uranium tetrafluoride ( $\mathrm{UF}_{4}$ or green salt) has been initiated. This activity is in support of the development of a cost-effective process to produce uranium-iron (U-Fe) alloy feed for the Uranium-Atomic Vapor Laser Isotope Separation (U-AVLIS) program. To date, five runs have been made by the Y-12 Plant Development Division to reduce green salt $\left(\mathrm{UF}_{4}\right)$ with magnesium. During this quarter, three runs were made to perfect the feeding system, examine feed rates, and determine the need for a crust breaker/stirrer. No material was drawn off in any of the runs; both product metal and by-product salt were allowed to accumulate in the reactor. 


\section{INTRODUCTION}

In support of the U-AVLIS program, the Y-12 Plant Development Division is carrying out scale-up experiments to reduce continuously uranium tetrafluoride $\left(\mathrm{UF}_{4}\right)$ to uranium metal using magnesium. Iron and a salt (sodium chloride, in this case) are used to reduce the operating temperature of the system. The method used is to feed the reactants (in powder form) into an alumina reaction chamber operating at about $1050^{\circ} \mathrm{C}$. As the magnesium fluoride $\left(\mathrm{MgF}_{2}\right)$ by-product is formed, it mixes with the sodium chloride $(\mathrm{NaCl})$ to produce a solution that melts at about $1030^{\circ}$ or $1040^{\circ} \mathrm{C}$ and seeps out of the reaction chamber. The uranium, as it is formed in small droplets in the molten magnesium or salt, alloys with iron, which is fed with the reactants to create an alloy of roughly $3 \mathrm{wt} \%$ iron, which is fully molten at about $925^{\circ} \mathrm{C}$. When the process reaches the production stage, the U-Fe alloy product will alsc be drawn out of the reaction chamber as it is formed, allowing the system to run continuously. 


\section{PRIOR WORK}

Initial proof-of-concept runs were made in a glove box at Santa Fe Alloys, Inc. The alumina reaction chamber was $1.5 \mathrm{in}$. in diameter, the maximum that could be accommodated in that system. Two runs made at the Y-12 Plant to examine material compatibility and to demonstrate salt withdrawal out of a $43 / 8$-in. reactor were reported earlier. 


\section{PRESENTATION OF EXPERIMENTAL WORK}

Three runs were made this quarter, all using the same configuration, to perfect the feed system and examine the use of crust breakers and stirrers. All three runs $(3,4$, and 5$)$ were set up as shown in Fig. 1.

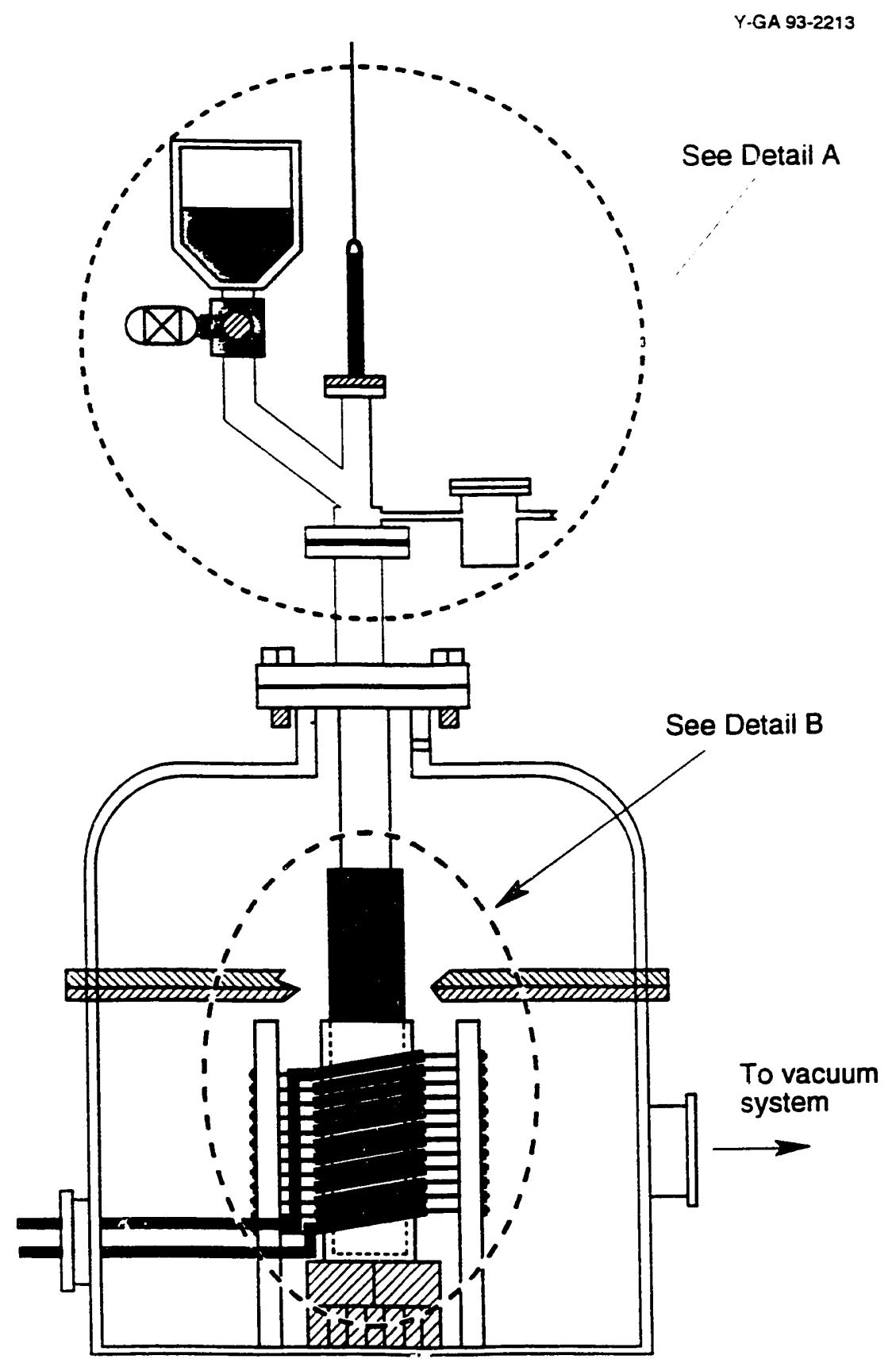

(a)

Fig. 1. Setup for Runs 3, 4, and 5. (a) Overall view of the furnace and feeder; (b) detail of feeder; (c) detail of reactor setup; and $(d)$ cutaway drawing of reactor. 


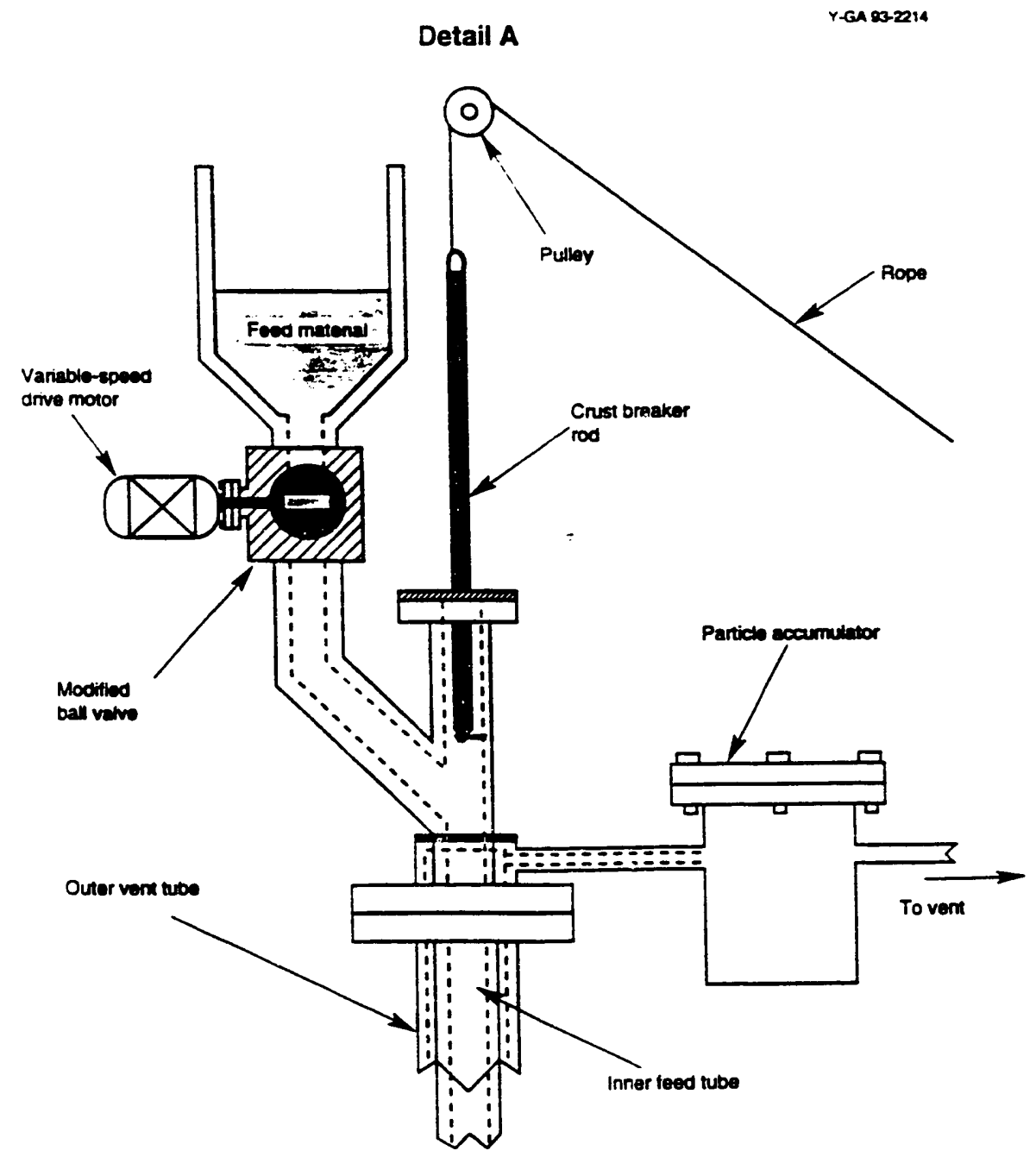

(b)

Fig. 1. Continued. 


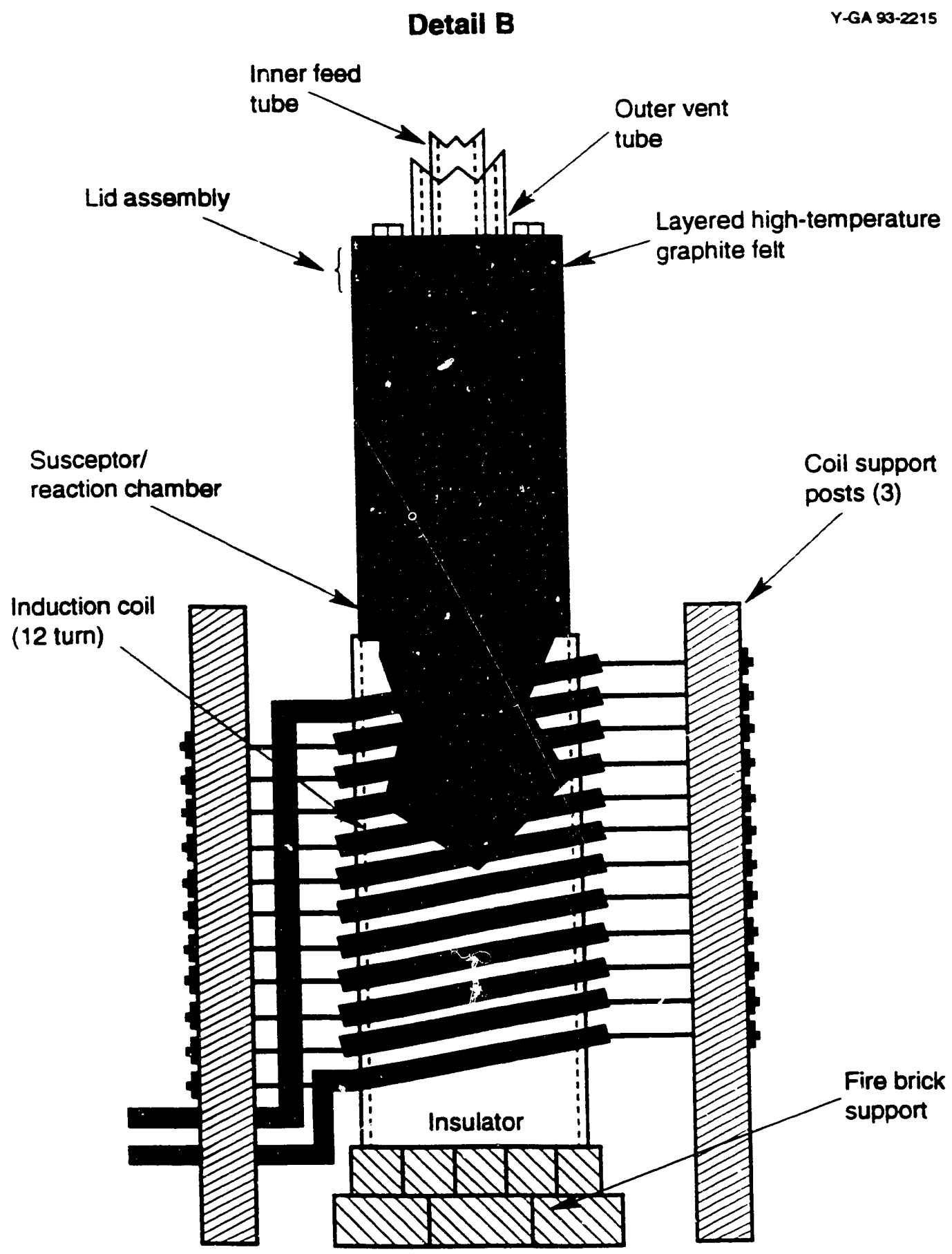

(c)

Fig. 1. Continued. 


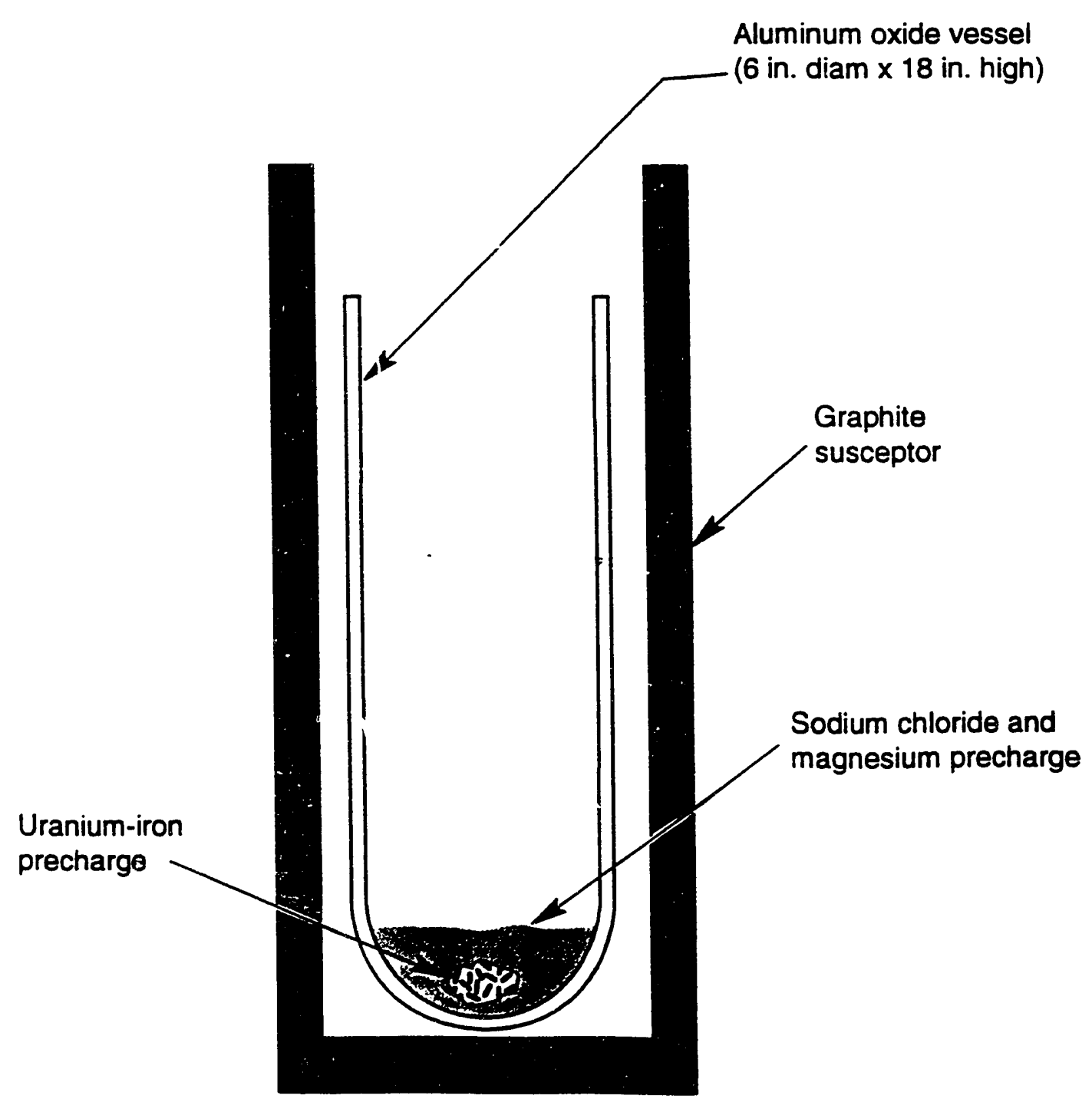

(d)

Fig. 1. Continued.

Run 3. For Run 3 and all subsequent runs, the $\mathrm{UF}_{4}$ was baked out at about $110^{\circ} \mathrm{C}$ to drive off moisture, then screened through a 35-mesh screen to remove lumps and any large foreign particles (some brownish granules, probably $\mathrm{CaMg}_{2} \mathrm{~A}_{12} \mathrm{~F}_{12}$ or some similar fluoride, were found in the $\mathrm{UF}_{4}$ ). Using the weight percent of feed shown in Table 1, the authors blended the powdered feed in 5-kg batches and loaded it into plastic bags. The reactor was precharged with all the U-Fe alloy produced in Runs 1 and 2 (to provide a molten pool for the uranium formed to accumulate) and with magnesium granules (to ensure a magnesium pool when feeding started) and sodium chloride (to wet the alumina). Weights of precharged material and product (where measured) for all three runs are given in Table 2. After the 
furnace was loaded, it was evacuated and purged several times, then the entire system was baked out under vacuum at $180^{\circ} \mathrm{C}$. After the system had cooled, the feed tube was installed, and the furnace was allowed to purge overnight.

Table 1. Weight percent of food material used for these experiments

\begin{tabular}{cc}
\hline Weight percent & Feed material \\
\hline 1.3 & $\mathrm{Fe}$ \\
60.9 & $\mathrm{UF}$ \\
15.2 & $\mathrm{Mg}$ \\
22.6 & $\mathrm{NaCl}$ \\
\hline
\end{tabular}

Table 2 Weights (in grams) of procharged material and product in Runs 3, 4, and 5

\begin{tabular}{crrrrrrr}
\hline & \multicolumn{2}{c}{ Precharged material } & & \multicolumn{2}{c}{ Product } \\
\cline { 2 - 3 } \cline { 7 - 8 } Run & $\mathrm{Mg}$ & U-Fe & $\mathrm{NaCl}$ & & $\mathrm{Mg}$ & U-Fe \\
\hline 3 & 1400 & 2910 & 906 & & 1119 & 5146 \\
4 & 708 & 1352 & 377 & & - & - \\
5 & 700 & 315 & 400 & & 600 & 3858 \\
\hline
\end{tabular}

A modified ball valve feeder, shown schematically in Fig. 1(b), was used for Runs 3, 4, and 5 . The valve ( 2 in. reducing) had a divider welded into the center, forming two pockets (Fig. 2); each full revolution of the valve then dropped two loads of feed into the reactor. The feed system delivered $1 \mathrm{~L}$ of blended feed in 20 revolutions. The valve was driven by a 6-rpm motor with a variable speed controller, allowing the speed to be reduced. The crust breaker, a 1-in.-diam steel rod, had a 1-in. fin welded to the bottom to give the rod more lateral range. During feeding, the breaker was pulled up out of the reactor.

Periodically during the run, the crust breaker was inserted into the reactor to make sure no crust was forming and to check the viscosities of the various layers. Roughly $10 \mathrm{~kg}$ of material had been fed when the run had to be aborted because of a clog in the feed tube. When the crust breaker was pulled out of the reactor, it was hot and had molten salt and magnesium clinging to it. During the run, as the powdered feed came down past the rod, some of it sintered to the rod and fin until finally the feed tube became completely blocked (Figs. 3 and 4).

Figure 5 shows the salt and metal product after it was broken out of the alumina reactor. The uranium alloy button, shown in Fig. 6, split away from the salt easily.

The salt appeared to be dirty and impure (Fig. 7). Figure 8 shows a polished fragment of the salt. Uranium droplets of varying sizes were found in the salt, one of the larger of which is shown in Fig. 9. A droplet entrapped in the salt was analyzed by electron microprobe. Although at first glance the droplets appear to be 2 phase (Fig. 10), most of them actually consist of alpha-uranium grains in a matrix of fine $\mathrm{Fe}_{2} \mathrm{U}+\mathrm{FeU}_{6}$ (Fig. 11). Rims of $\mathrm{FeU}_{6}$ surround the alpha uranium grains. 


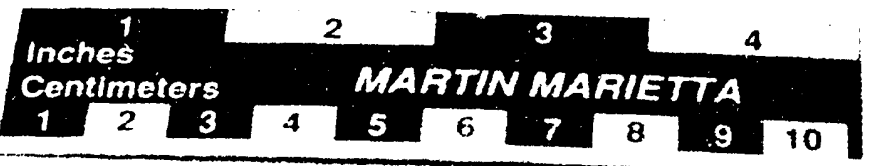

Fig. 2. Feed valve ball. 
$\therefore \times 24 x$

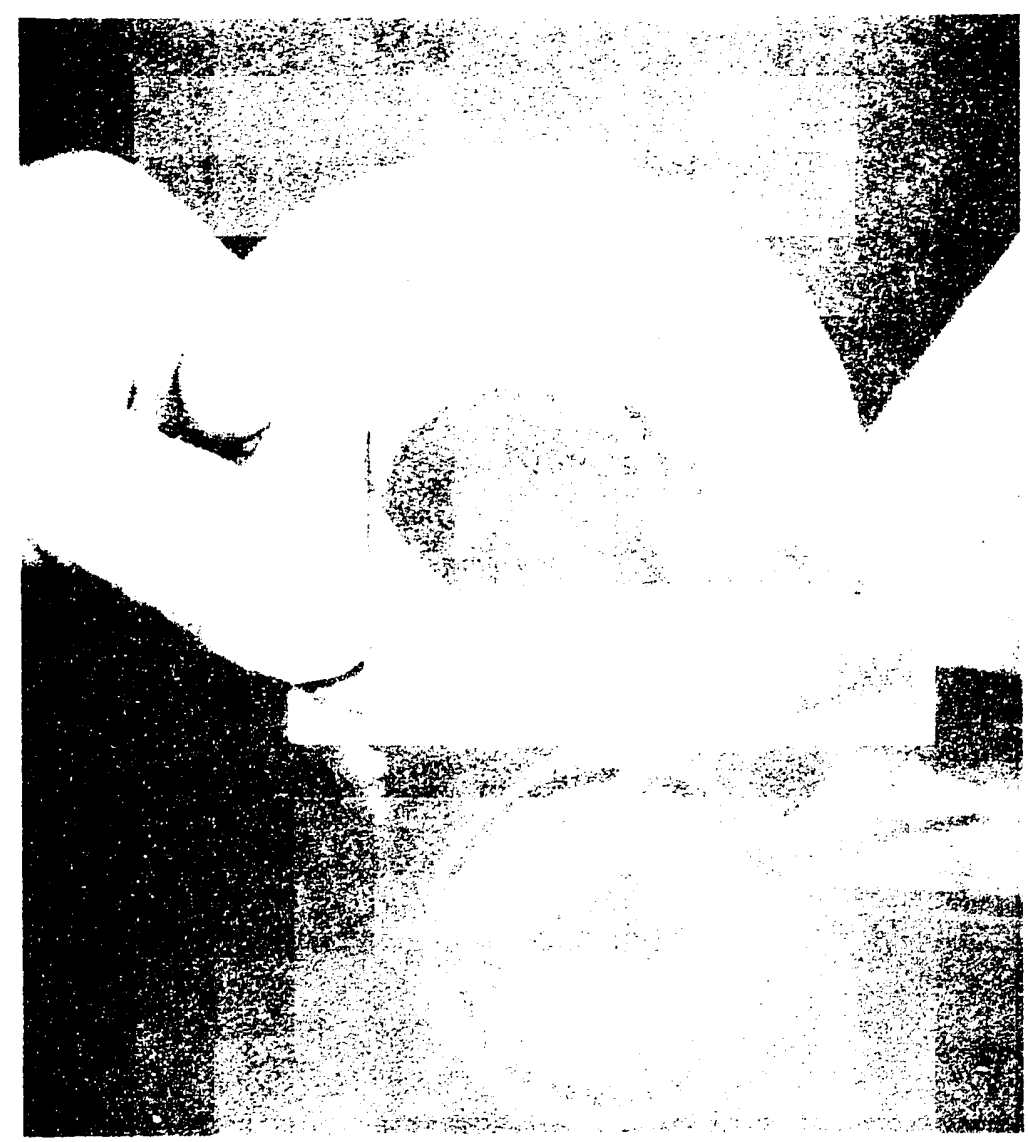

lis: :

:11:

channel is a viat:

$\therefore 157$
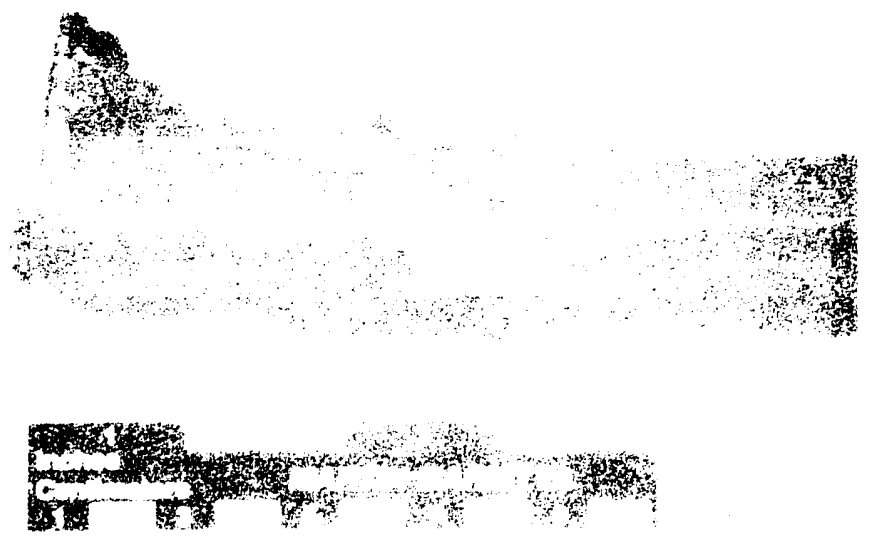

Fig. 4. Bnd of the buther ath sed material sintered on ond 


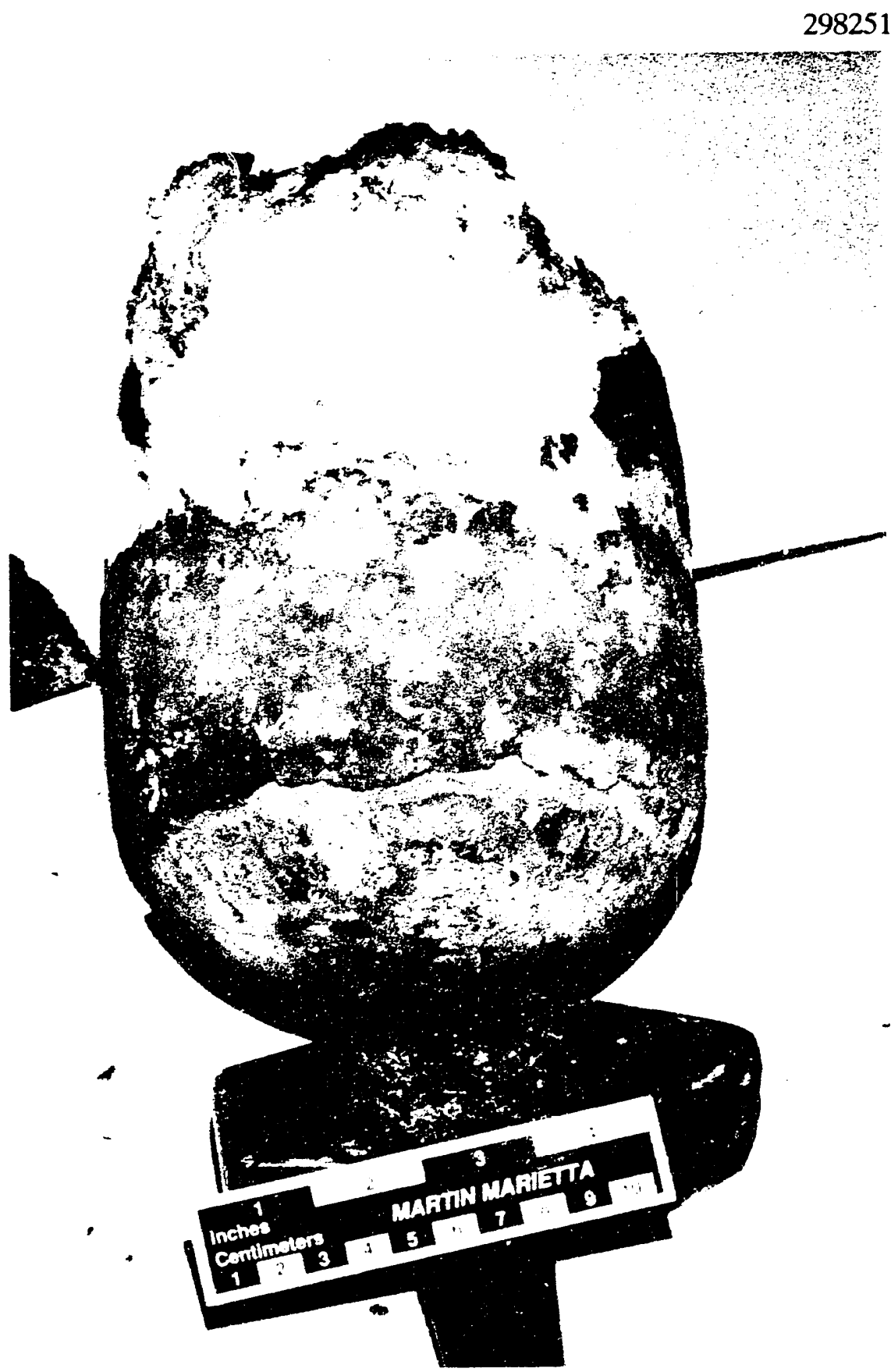

Fig. 5. Magnesium layer on top, salt with magnesium droplets, and uranium button at bottom. 

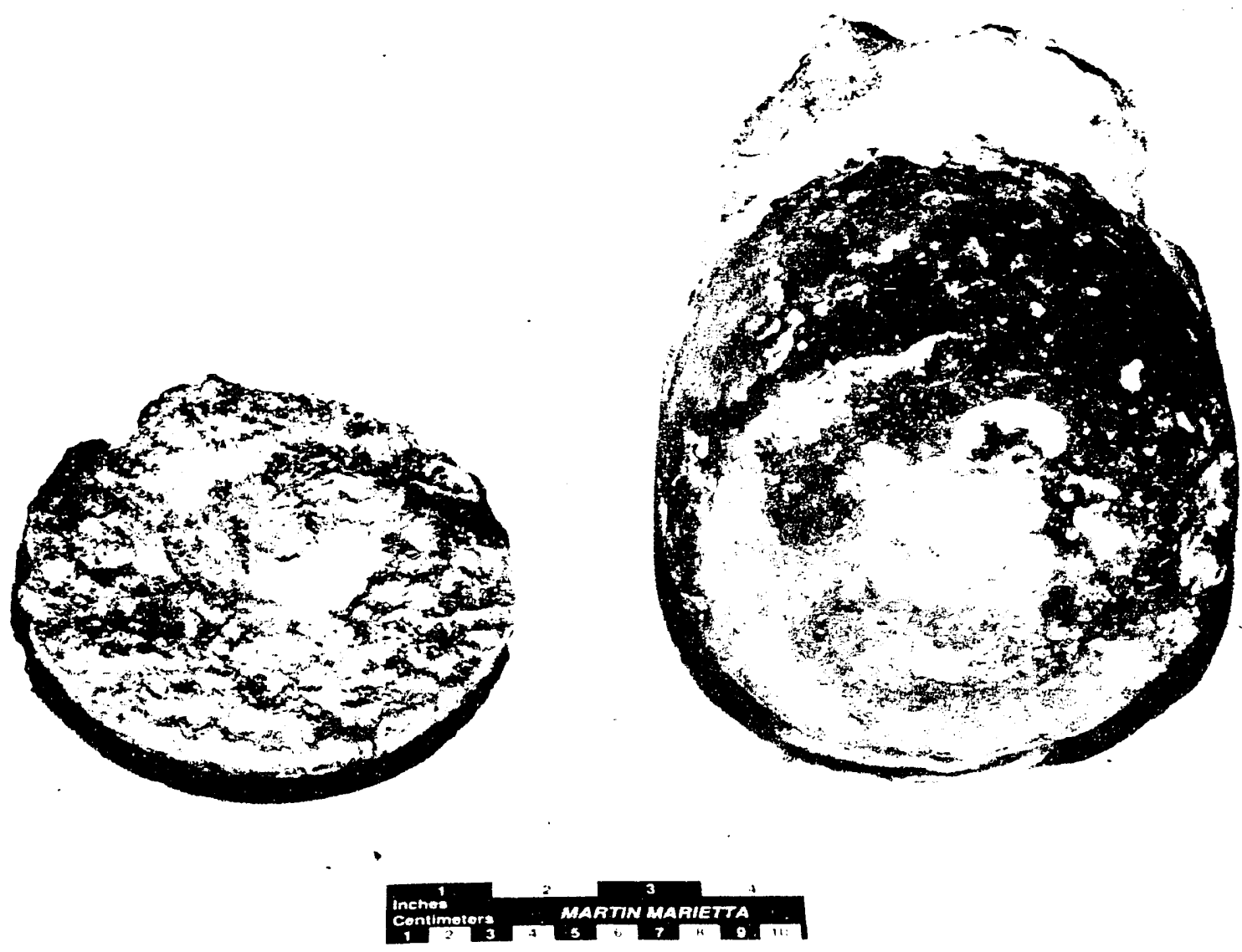

Fig. 6. Product from Run 3. At left, top of uranium button; at right, bottom of salt layer. 


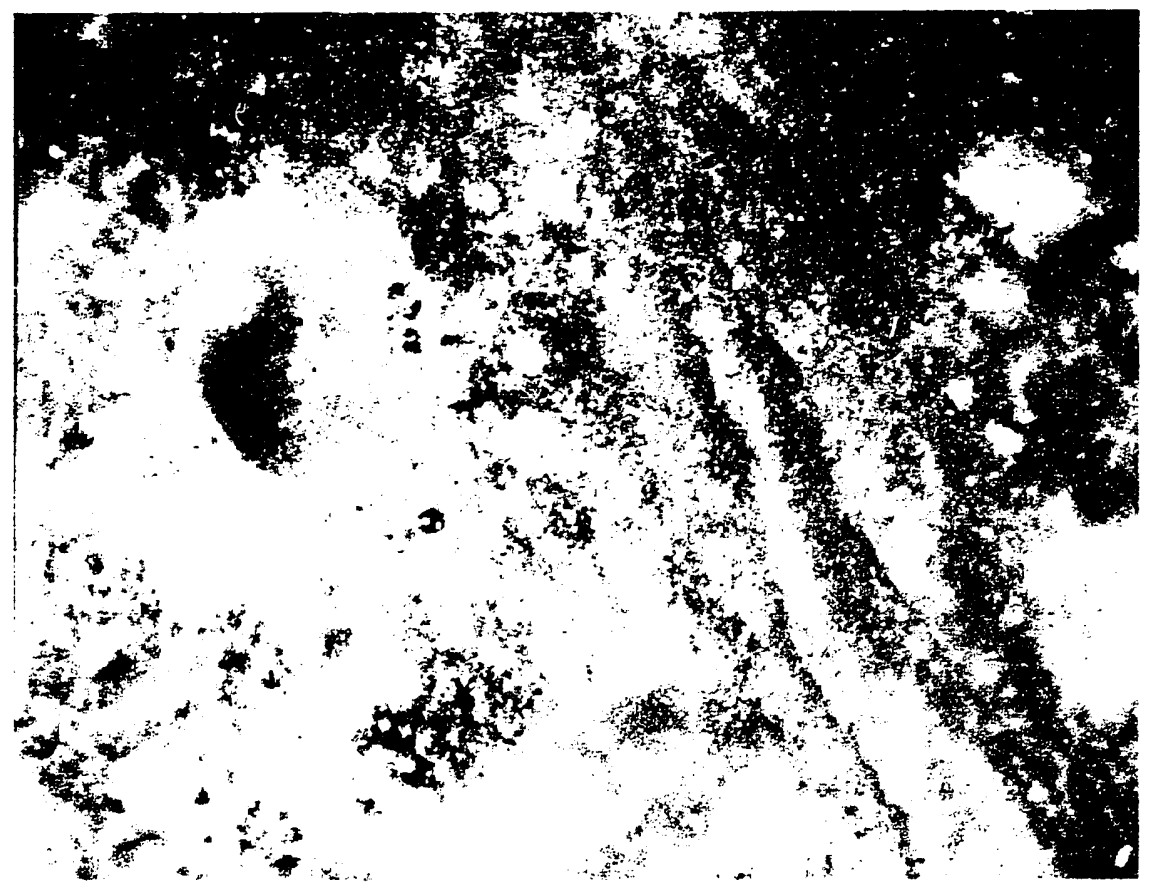

Fig. 7. Macrograph of impure salt.

MS-9.3-()() ()4-6

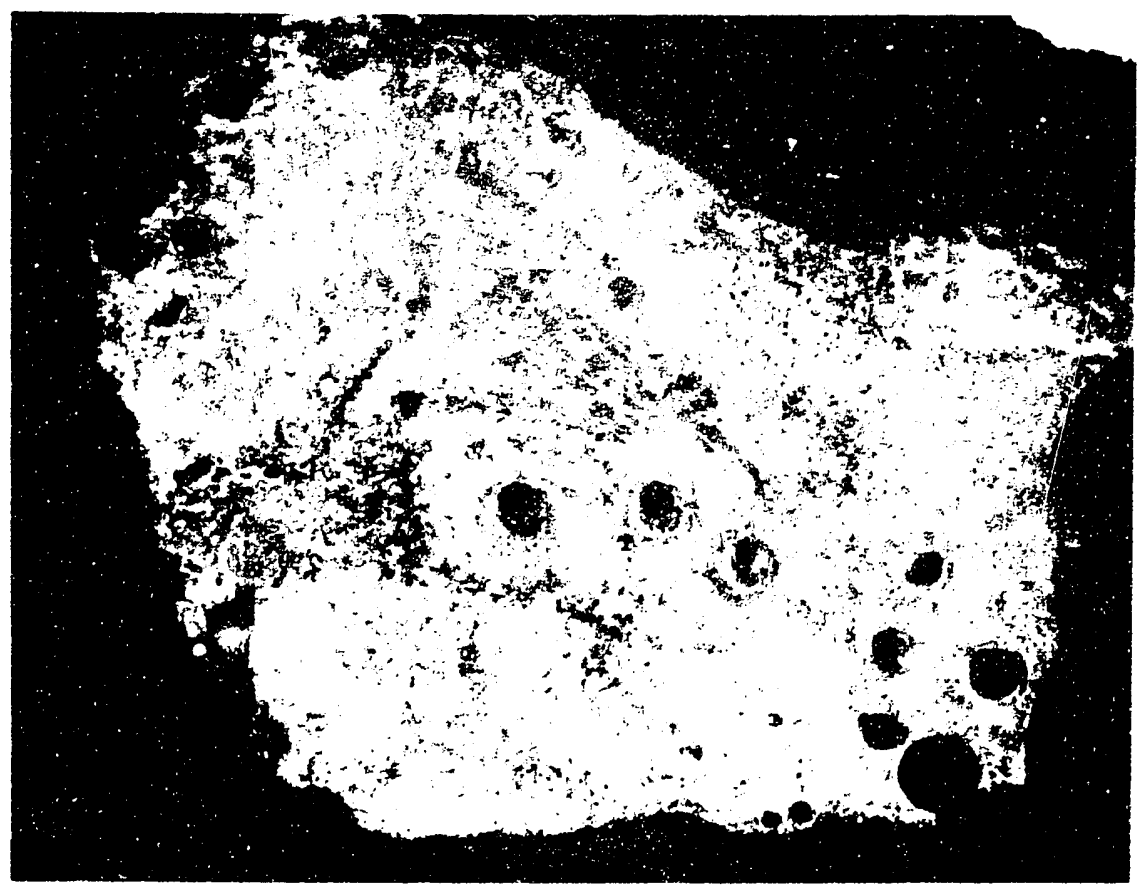

Fig. 8. Macrograph of a polished fragment of salt from Run 3. The black circles are uranium, and the gray magnesium that encircles the droplets can be seen on some. 


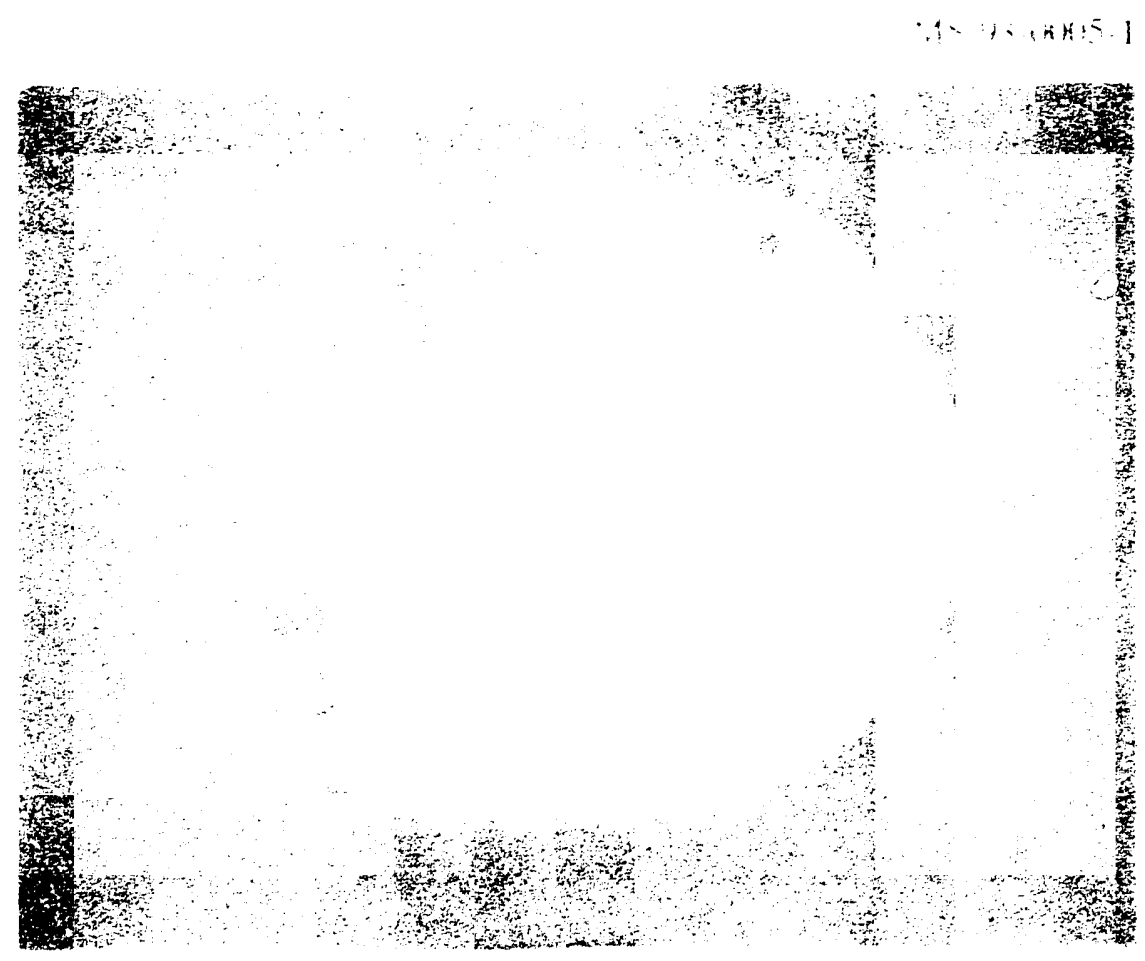

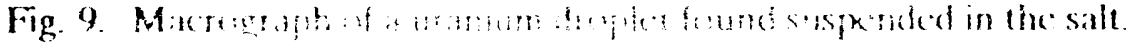

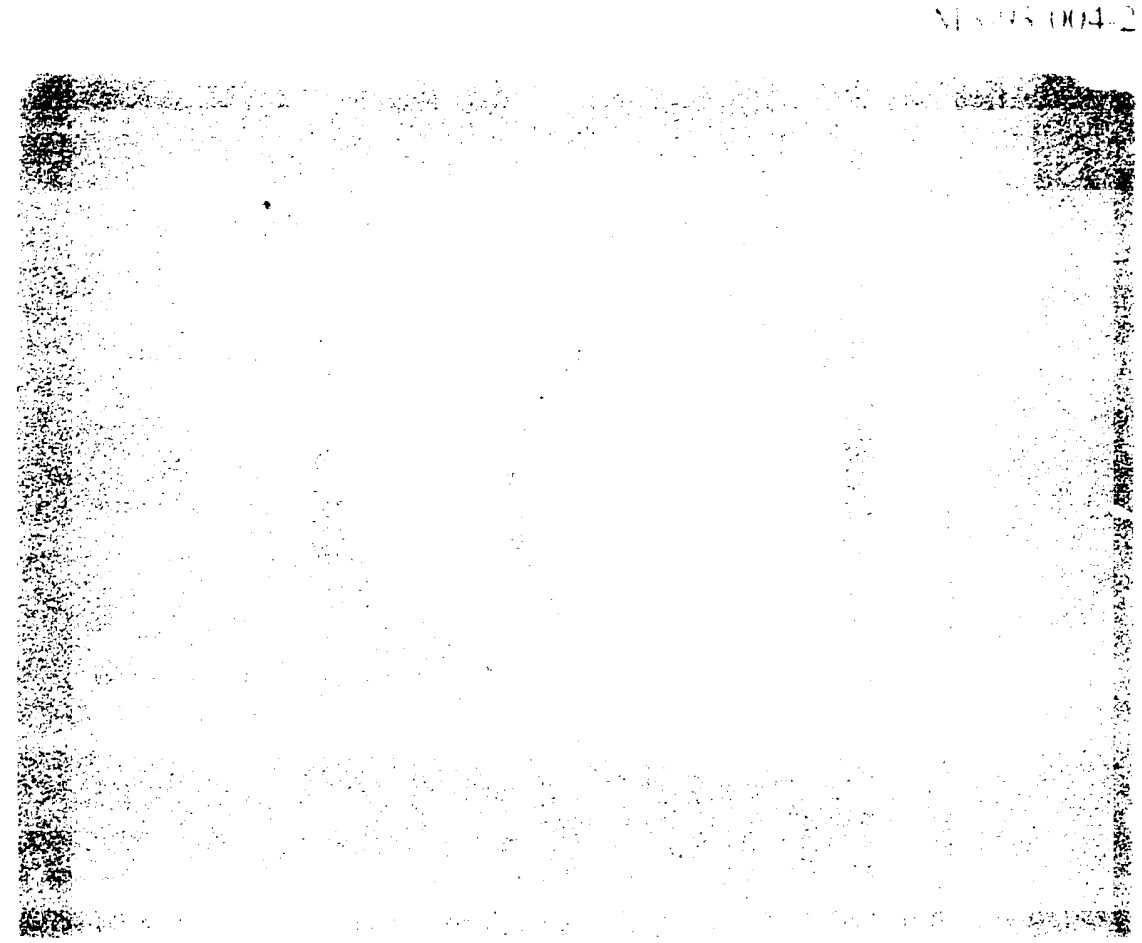

rig. 


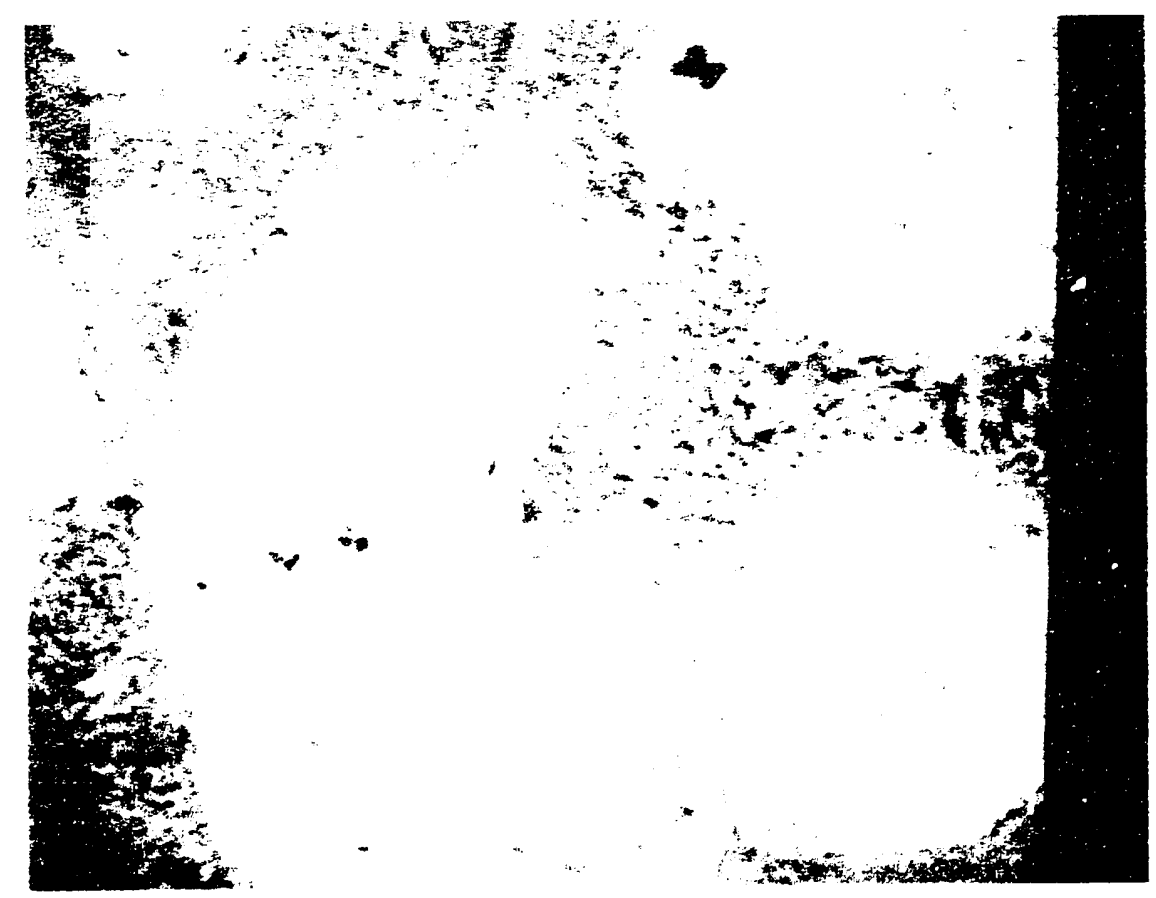

Fig. 11. Backscattered electron image of a uranium droplet. The white grains are alpha-uranium; they are surrounded by $\mathrm{FeU}_{6}$. The dark arcas are a 2-phase mixture of $\mathrm{FeU}_{6}$ and $\mathrm{Fe}_{2} \mathrm{U}$. ( $\left.(80) \mathrm{X}\right)$

Run 4. Because the feed system did not perform as desired, Run 3 was repeated with a slight modification: the finned 1 -in. crust breaker rod was discarded for the $3 / 4$-in. rod with no fin that was used in Run 2. The furnace setup was the same as that for Run 3, but less material was precharged (see Table 2). During the evacuation and purging phase, the authors observed that the furnace had a high leak rite.

Despite the fact that the furnate atmosphere was not as clean as desired, the run was begun and the furnace was heated $101070{ }^{\circ} \mathrm{C}$. Because the glow from the reactor could not be seen, the crust breaker was inserted to check for obstructions in the feed tube; none was found. As the rod was being pulled out of the reactor, it slipped.

Feeding was begun with the feed valve turning at top speed $(6 \mathrm{rpm})$. Three bags of material ( $5 \mathrm{~kg}$ each) were fed this way, each taking about 5 min to feed. When the rod was inserted after feeding was complete, a crust layer appeared to be in the reactor.

Figure 12 shows the reactor and the graphite susceptor as they were removed from the furnace. When the crust breaker rod had slipped at the beginning of the run, it had pierced a hole in the alumina, allowing the uranium we escape into the graphite susceptor (Figs. 13 and 14). The uranium adhered strongly to the graphite through a layer of uranium carbide. The uranium could not be broken free of the graphite (Fig. 15) and was eventually sawed off.

When the reactor was broken open, a layer of reacted but unmelted feed several inches thick was found (Fig. 16). Below this "crust" was a void. then the magnesium pool (Fig. 17), followed by gray magnesium flucride-sodium chloride salt (Fig. 18). Constituents of these layers, as determined by $\mathrm{X}$-ray diffraction. are shown in Table 3. 


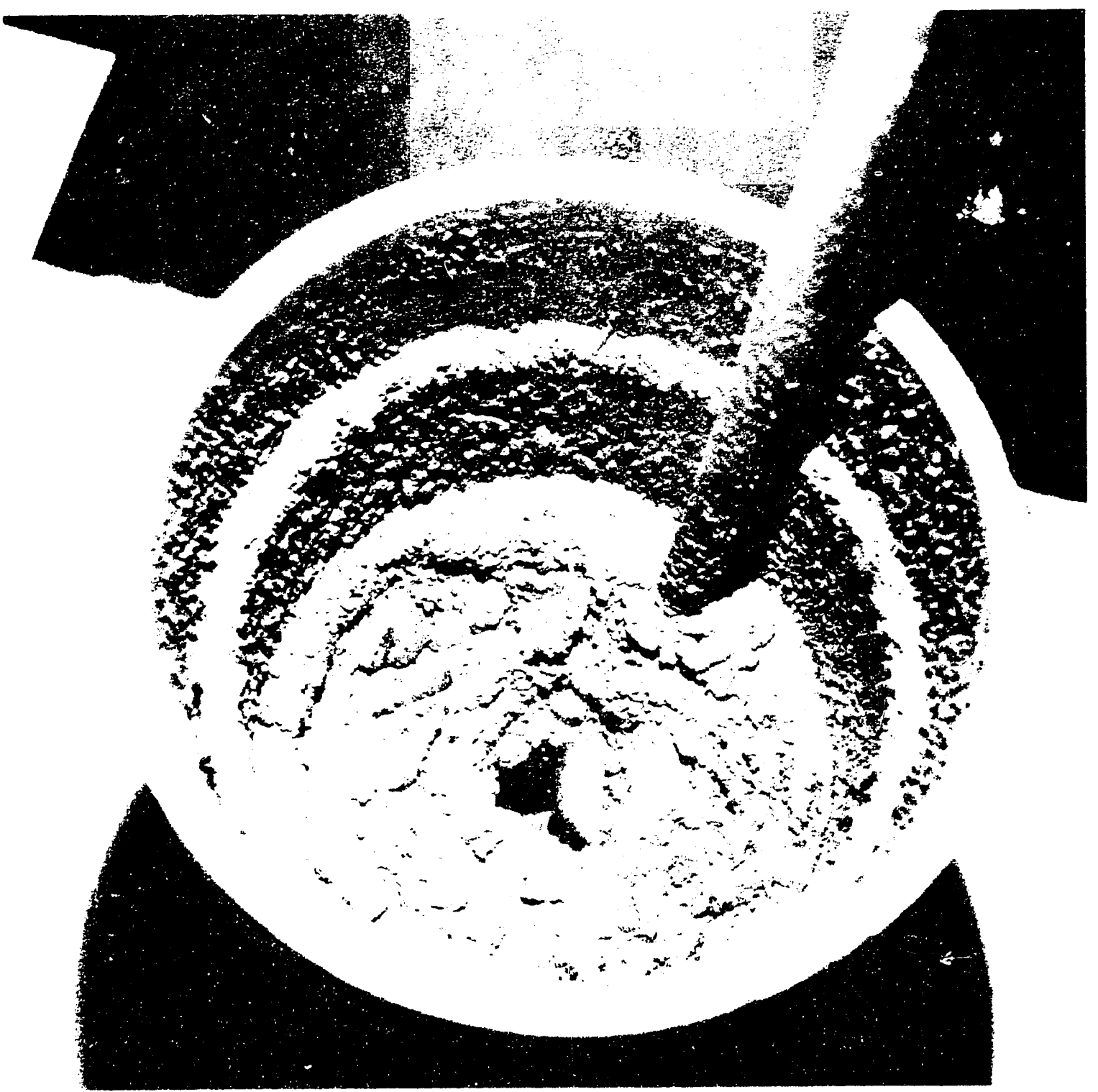

Fig. 12 Reactor and susceptor from Run 4. The hole in the center is where the crust breaker rod was inserted at the end of the run. Iligh oxygen kevels in the furnace caused an orange uranium oxide coating. 


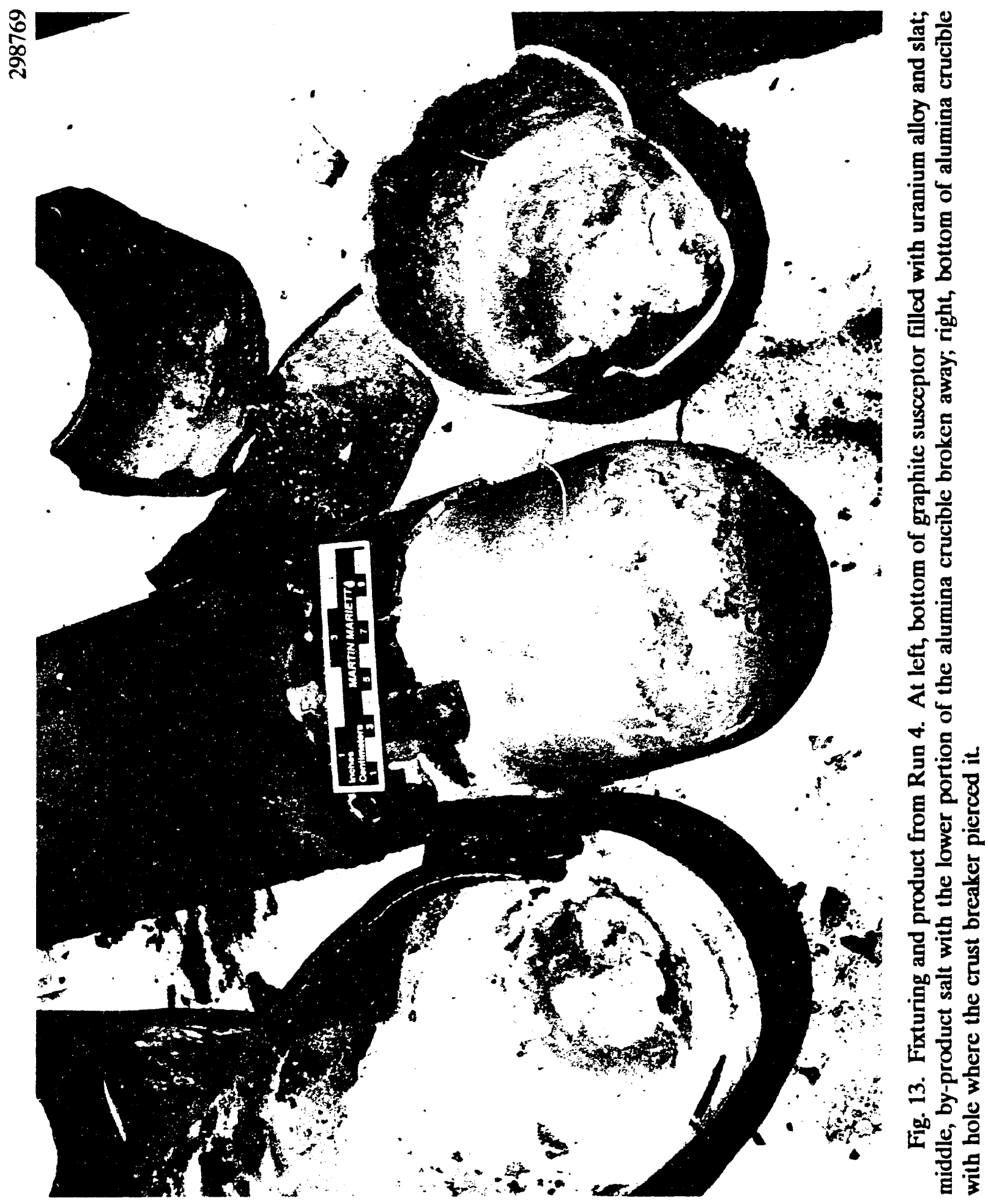




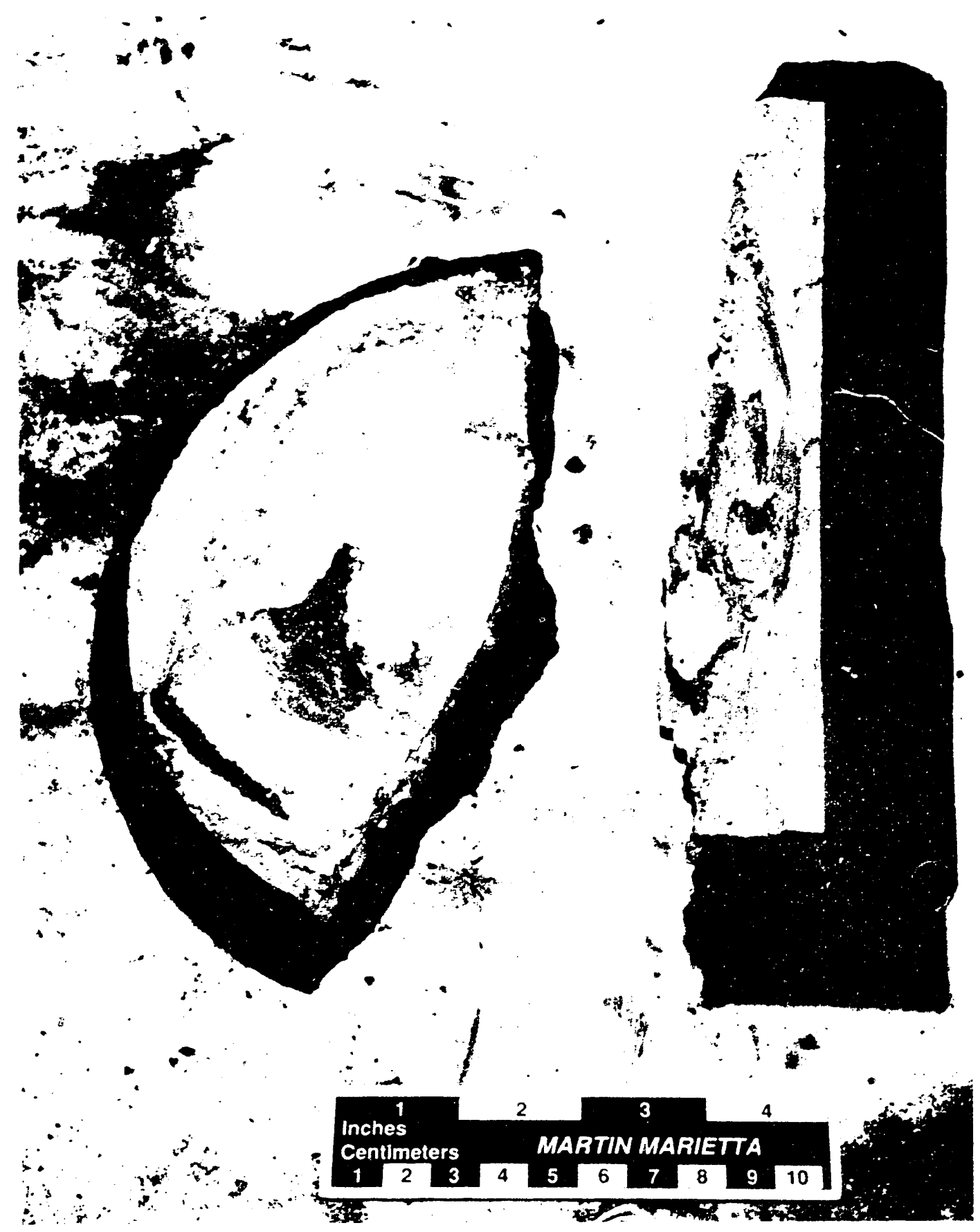

Fig. 14. Uranium alloy in the bottom of the graphite susceptor. 

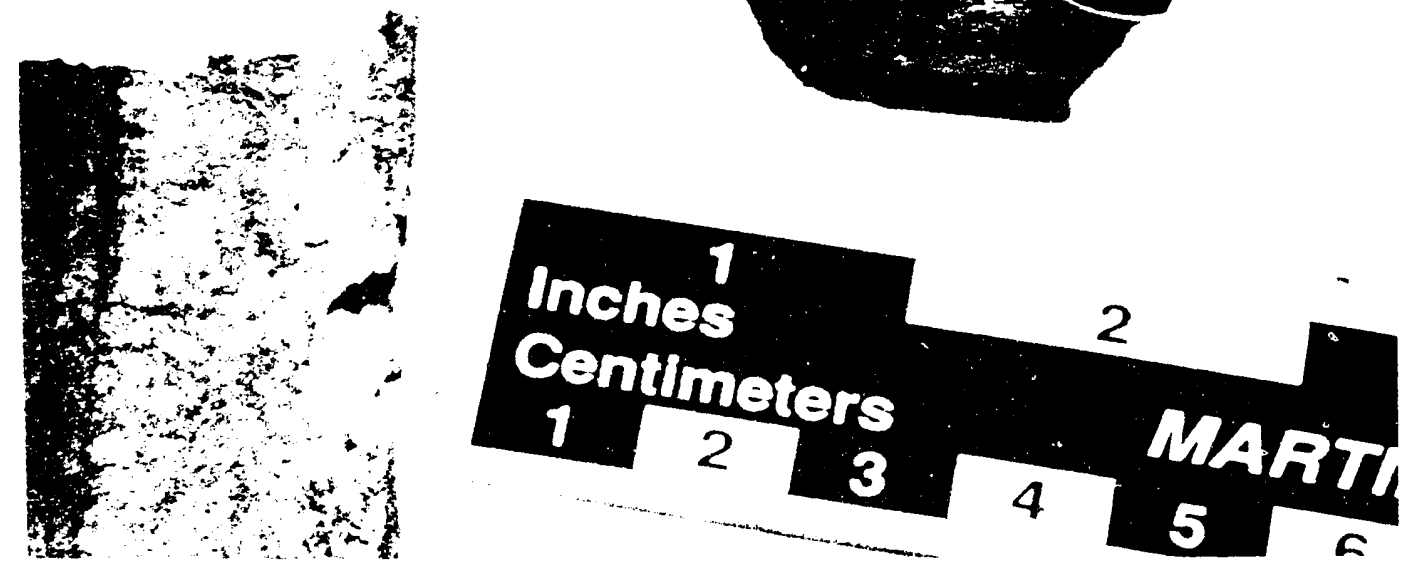

Fig. 15. Uranium alloy adhering to the bottom of the graphite susceptor. The graphite would not break free from the uranium, but instead broke into smaller pieces of graphite and uranium. 


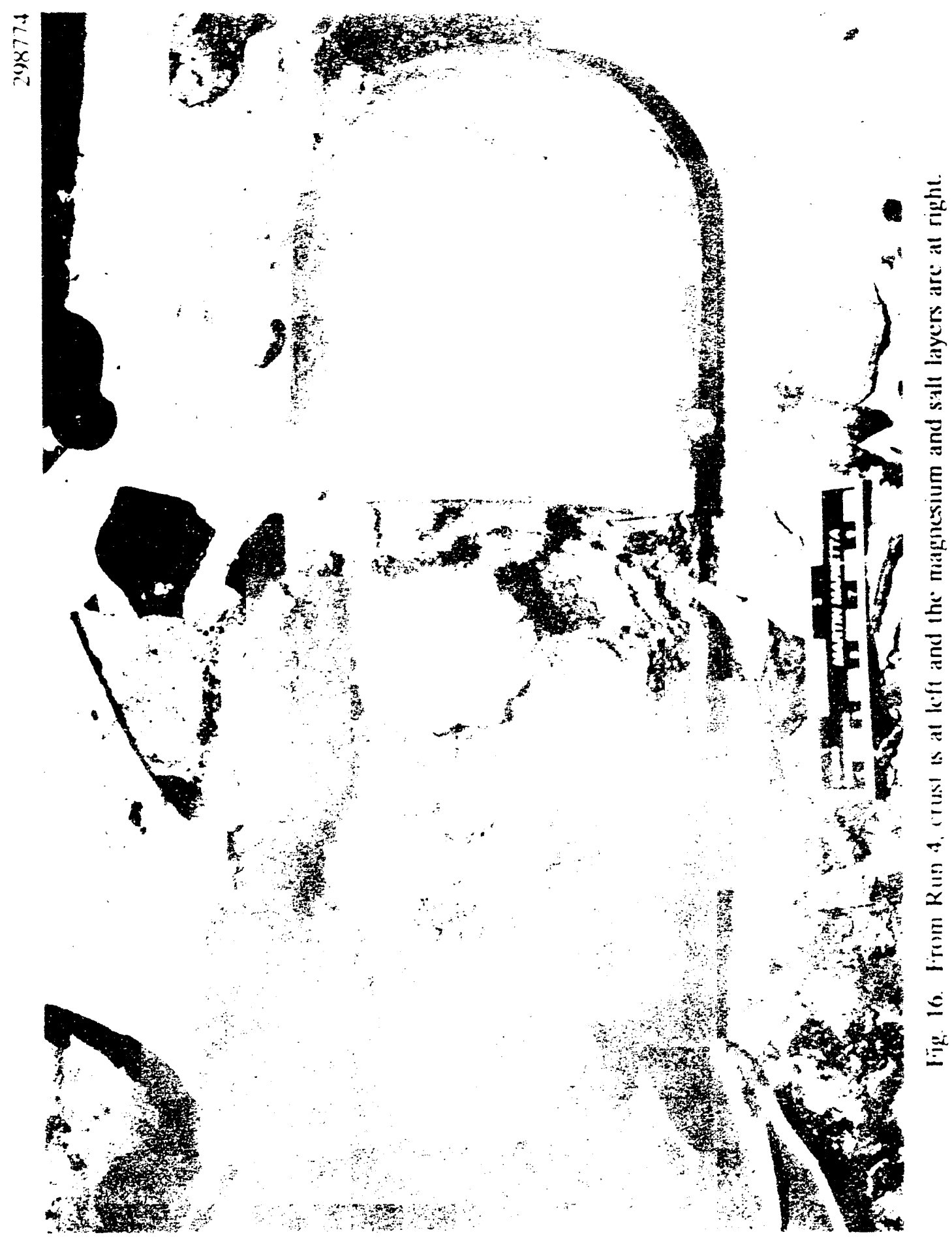


298765

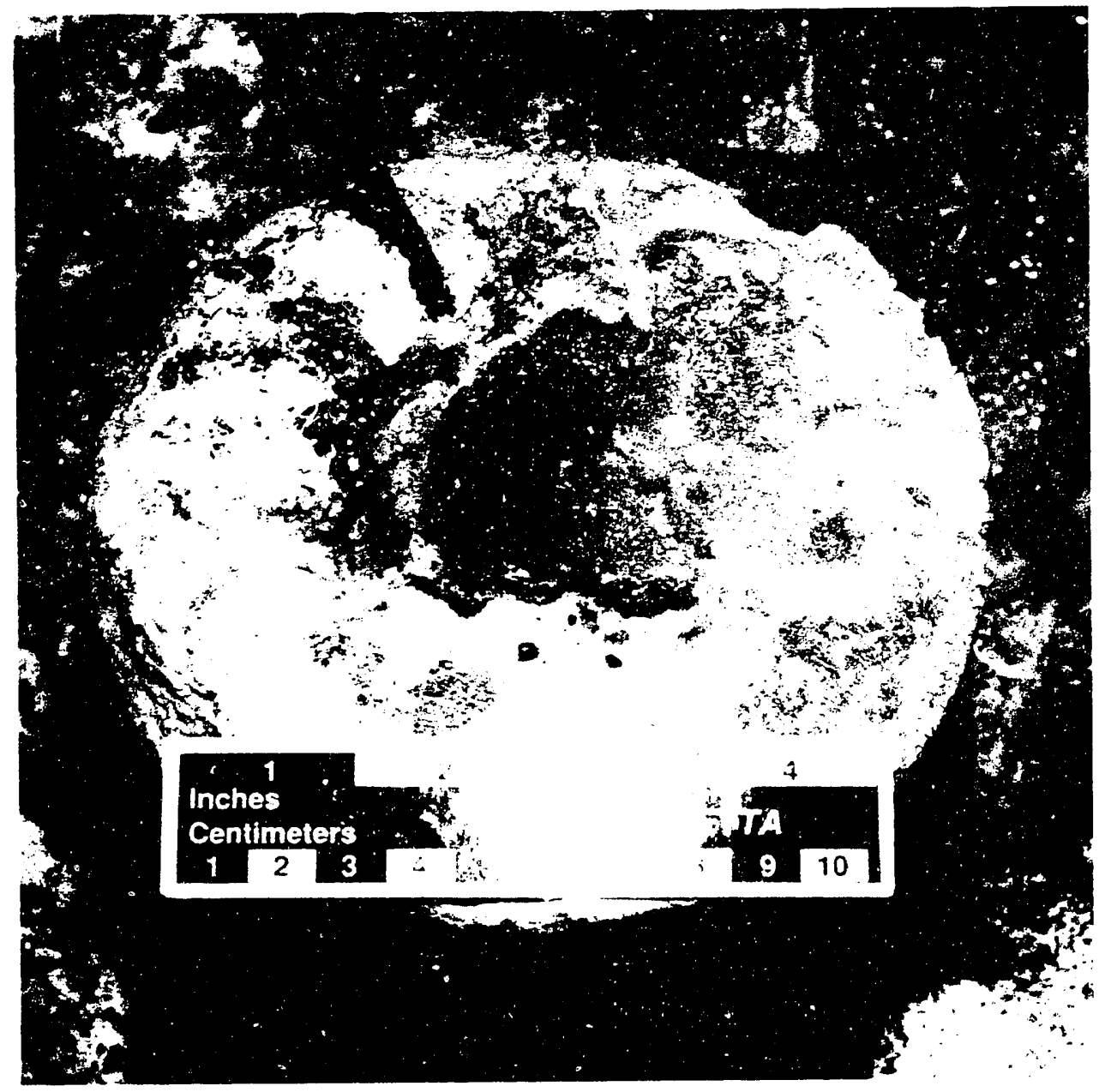

Fig. 17. Below the protective covering of unreacted feed, the magnesium pool was bright and shiny. 

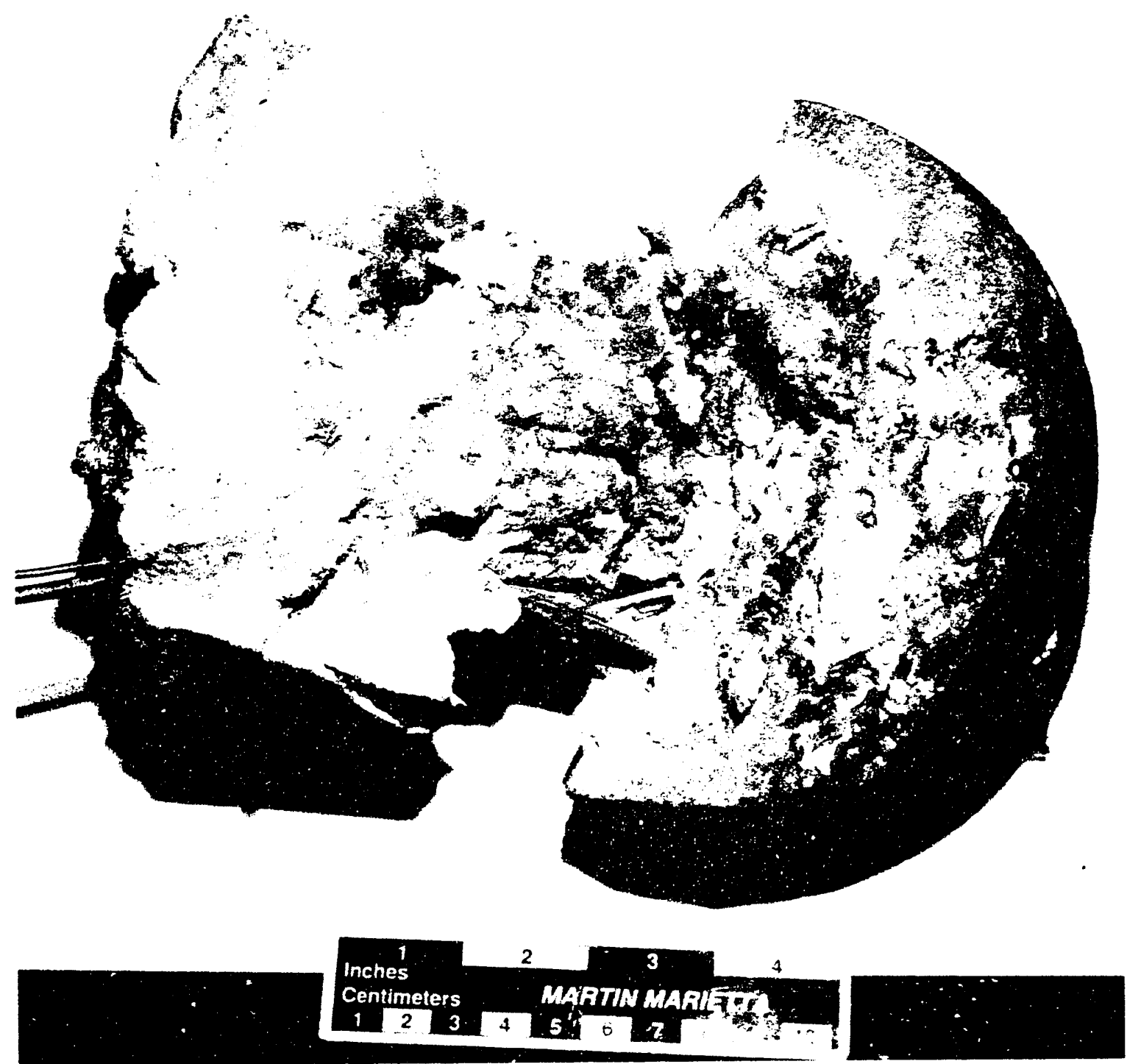

Fig. 18. Gray, poorly separated magnesium fluoride-sodium chloride salt. The wires running through the salt are thermocouples, originally protected in an alumina tube. 
Table 3. Constituents of the various layers in the Run 4 reactor as determined by X-ray diffractions

\begin{tabular}{lccc}
\hline & Major constituents & Intermediate constituents & Minor constituents \\
\hline Top of crust & $\mathrm{Mg}, \mathrm{NaCl}, \mathrm{UO}_{2}$ & & $\mathrm{MgO} \mathrm{UF}_{4}, \mathrm{SiO}_{2}$ \\
Center of crust & $\mathrm{NaCl}, \mathrm{UO}_{2}$ & $\mathrm{MgF}_{2}$ & Possible uranium \\
White salt & $\mathrm{NaCl}, \mathrm{MgF}_{2}$ & & \\
Gray salt & $\mathrm{NaCl}, \mathrm{UO}_{2}$ & $\mathrm{MgF}_{2}$ & \\
\hline
\end{tabular}

With the crust-breaker rod pulled completely out of the furnace during feeding, none of the feed adhered to the inside of the feed tube (Fig. 19). A thermocouple was placed inside the feed tube to monitor the temperature at the end of the tube. Although the tube initially reached $600^{\circ} \mathrm{C}$, it quickly dropped below $500^{\circ} \mathrm{C}$ after feeding began.

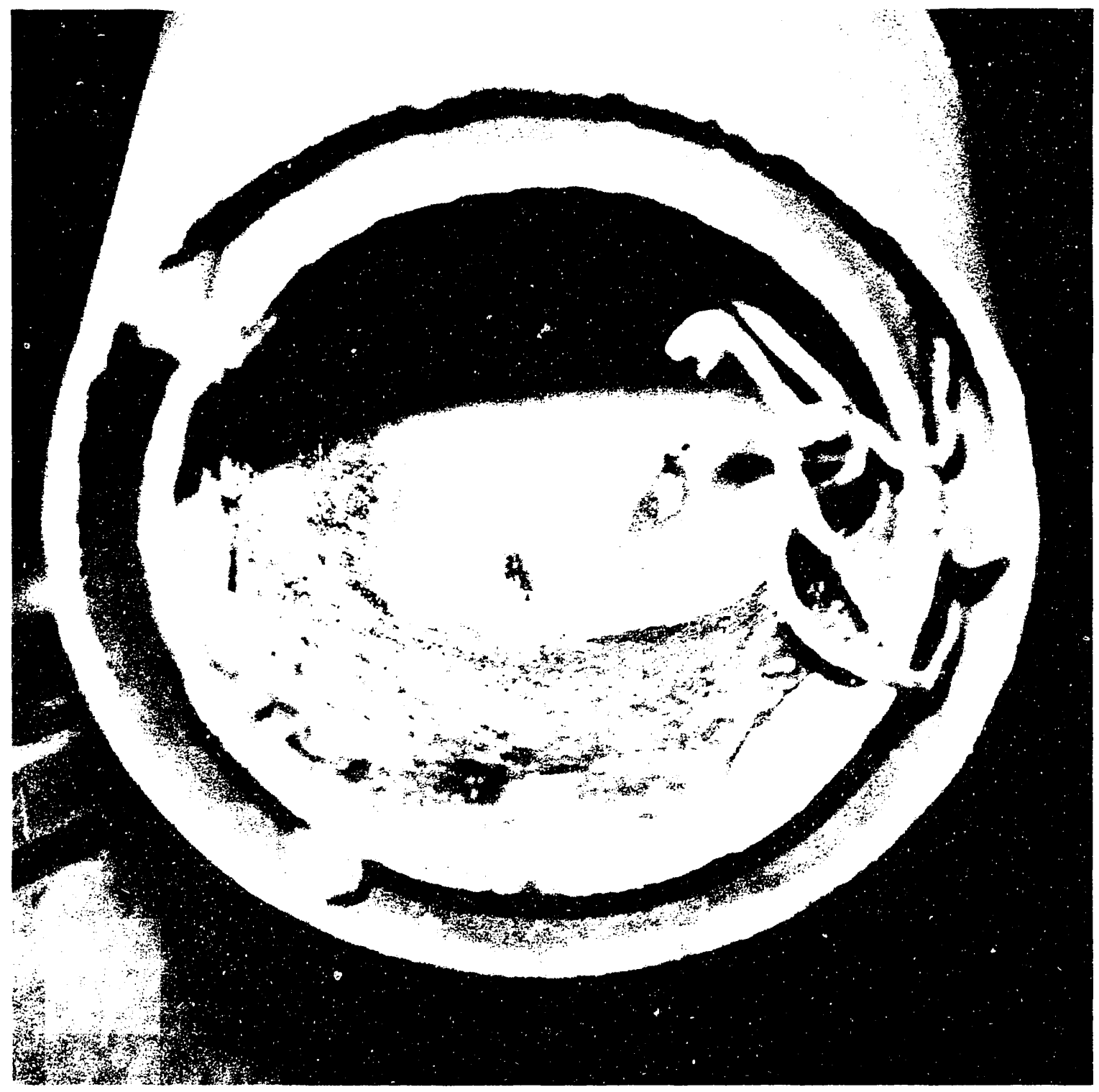

Fig. 19. Bottom of the feed tube-no feed buildup this time. The wire tied to one side is a thermocouple. 
The feed valve was dismantled after Run 4 to check the seats for wear. Because the original seats had been badly scarred, new seats were made from aluminum bronze.

Because feeding was completed within about $30 \mathrm{~min}$, after which the power to the system was cut, the salt did not have sufficient time at temperature for settling of the uranium to occur (Fig. 20). With the salt withdrawal system in place, these droplets would be swept out of the withdrawn salt because the magnesium-coated uranium alloy pool acts as a filter, entrapping and coalescing droplets of both magnesium and uranium alloy.

298773

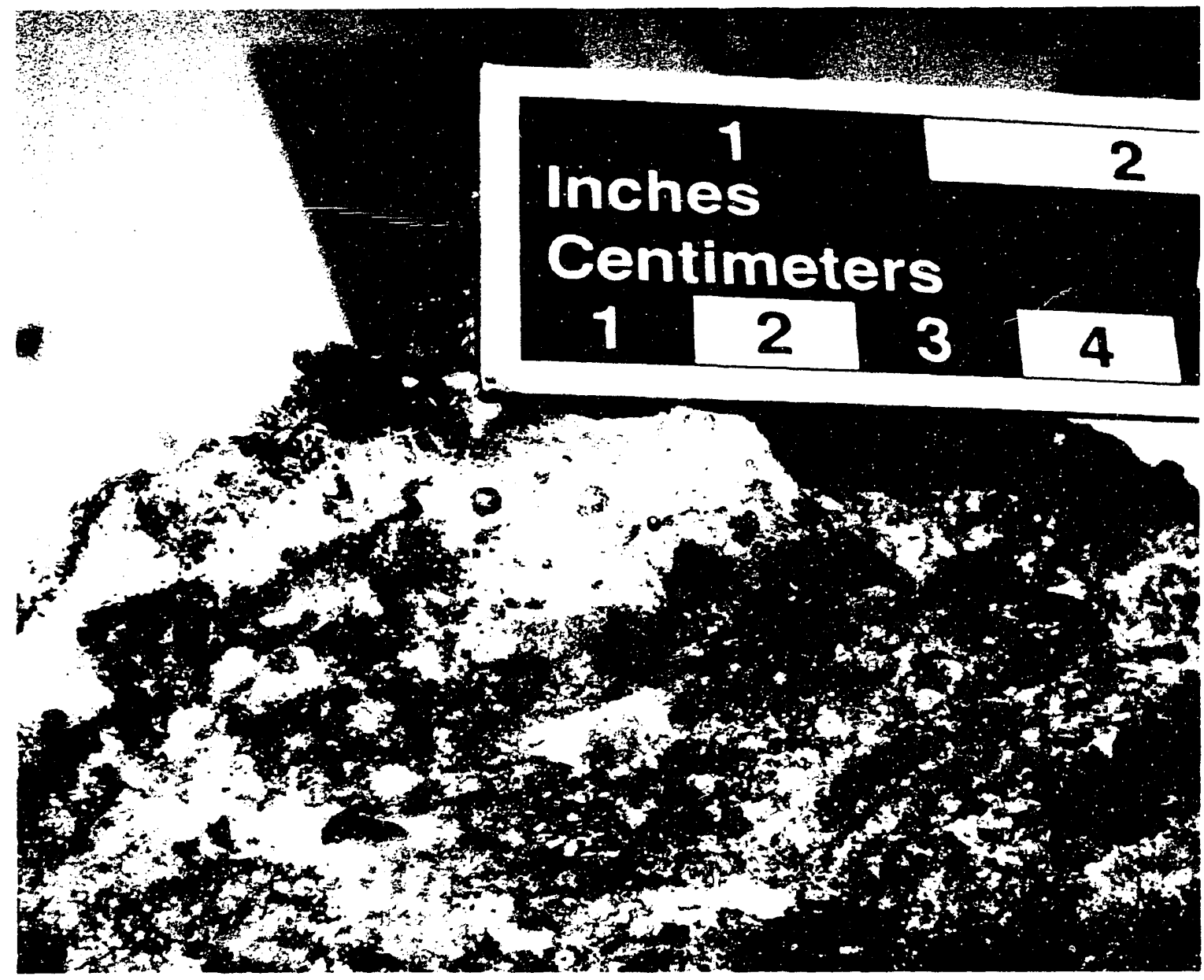

Fig. 20. Impure salt from Run 4. Not allowed sufficient time at temperature for settling to occur, the salt is riddled with droplets of metal.

Run 5. Because Run 4 still did not meet either goal of providing a large mass of uranium alloy or determining whether crust breaking/stirring was required, the run was repeated. For Run 5, nothing was changed from the Run 4 setup except that a longer purge time was employed to provide a cleaner atmosphere.

Because the crust layer at the top could have been the result of a number of things (including lack of stirring, feeding too fast, or too much oxygen in the system), feeding was done slowly while the authors watched the activity in the reactor through the sight glass for 
most of the run. The tube was kept relatively clear of dust with a hard flow of argon through the feed tube so that the authors could see the reaction. As the feed dropped down into the reactor, the pool was momentarily obscured. The feed rate was timed so that the red glow of the molten pool reappeared just before another load of feed was dropped. At this rate, the system was allowed to recover thermally during feeding so that no buildup of cold feed could occur.

The ideal feed rate was $20 \%$ of full speed (just over $1 \mathrm{rpm}$ ), but the motor could not sustain this low speed with the added drag created by the new metal valve seats. When the valve stalled repeatedly, a similar feed rate was attained by turning the motor off and on.

After about 2.5 bags of feed had gone into the system, the surface began to skin over. The skin was broken with the crust breaker, then feeding resumed at a somewhat slower rate. When the surface of the magnesium still would not remain clear, the rest of the feed ( 2 to $3 \mathrm{~kg}$ ) was fed at about $3 \mathrm{rpm}$.

When the furnace was unloaded and the feed tube was pulled from the furnace the next day, fine magnesium droplets adhering to the end of the feed tube burned. This burning indicates that the atmosphere in the furnace was clean.

Sintered material again was built up in the top of the vessel, but this time the surface appeared to be clean and oxide-free (Fig. 21). Again, a void existed between the unreacted feed layer and the magnesium pool. The salt layer was white, except for the bottom $1 / 4$ in. or so, which still contained metal droplets (Fig. 22). Some gray banding was also present at the bottom of the white salt layer (Fig. 23). Figure 24 shows the uranium button.

The scale drawing of Run 5 (Fig. 25) shows that the reason for the crust layer buildup is that the reaction products rise to a height at which the incoming reactants are out of the heat zone. The temperature at the top thermocouple never exceeded $900^{\circ} \mathrm{C}$. Until the magnesium level rose to this point, the reaction proceeded well with no stirring required. Turbulence in the magnesium, visible from the sight port, prevented any skinning over. Had the uranium alloy and by-product salt been drawn off during the reaction, the product height in the reactor could have been controlled, and the reaction could have been kept at the proper temperature indefinitely.

Casting 1. Uranium alloy recovered from Runs 2 through 5 was remelted under vacuum into an $8.3-\mathrm{kg}$ slab (Figs. 26 and 27). The magnesium, above its boiling point at $1050^{\circ} \mathrm{C}$ and under a rough vacuum, caused the uranium alloy to spatter out of the crucible and onto the alumina insulator (Fig. 28). The purpose of the remelt was not only to consolidate the uranium produced thus far but also to separate it from the magnesium that coated each button.

Results of Analysis and Discussion. Uranium alloy from Casting 1 and Runs 3 and 4 was chemically analyzed. The uranium alloy from both runs was inhomogeneous enough that compositional variations could be seen with the naked eye. For this reason, the 1-g aliquots used by the Plant Laboratory were not representative of the overall sample, and the uranium, iron, and magnesium contents listed in Table 4 are averages of several aliquots. That the numbers listed in Table 4 do not total $100 \%$ is also due primarily to the inhomogeneity. 
298780

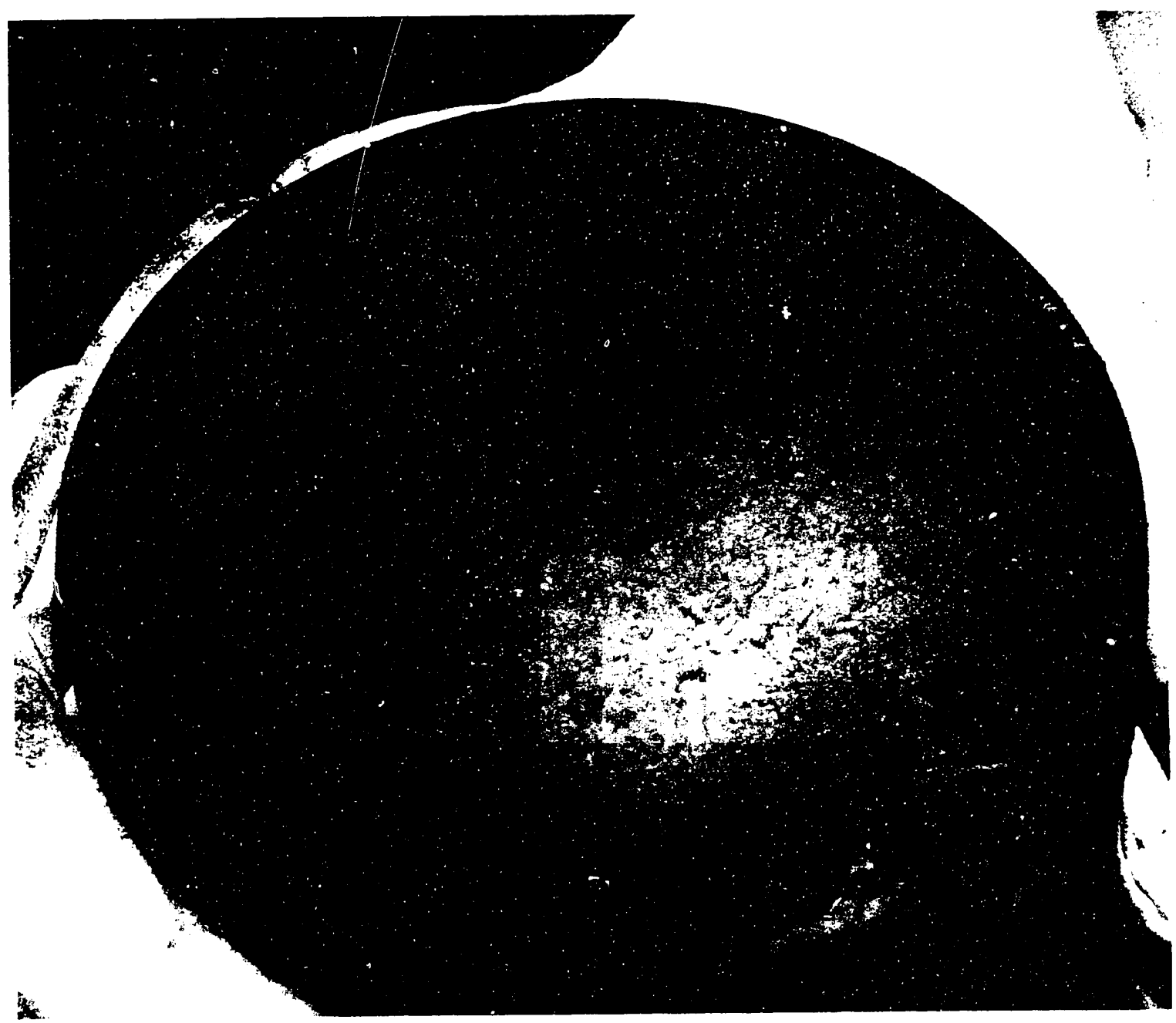

Fig. 21. Run 5 shows alumina vessel with layer of green unreacted foed on top. 


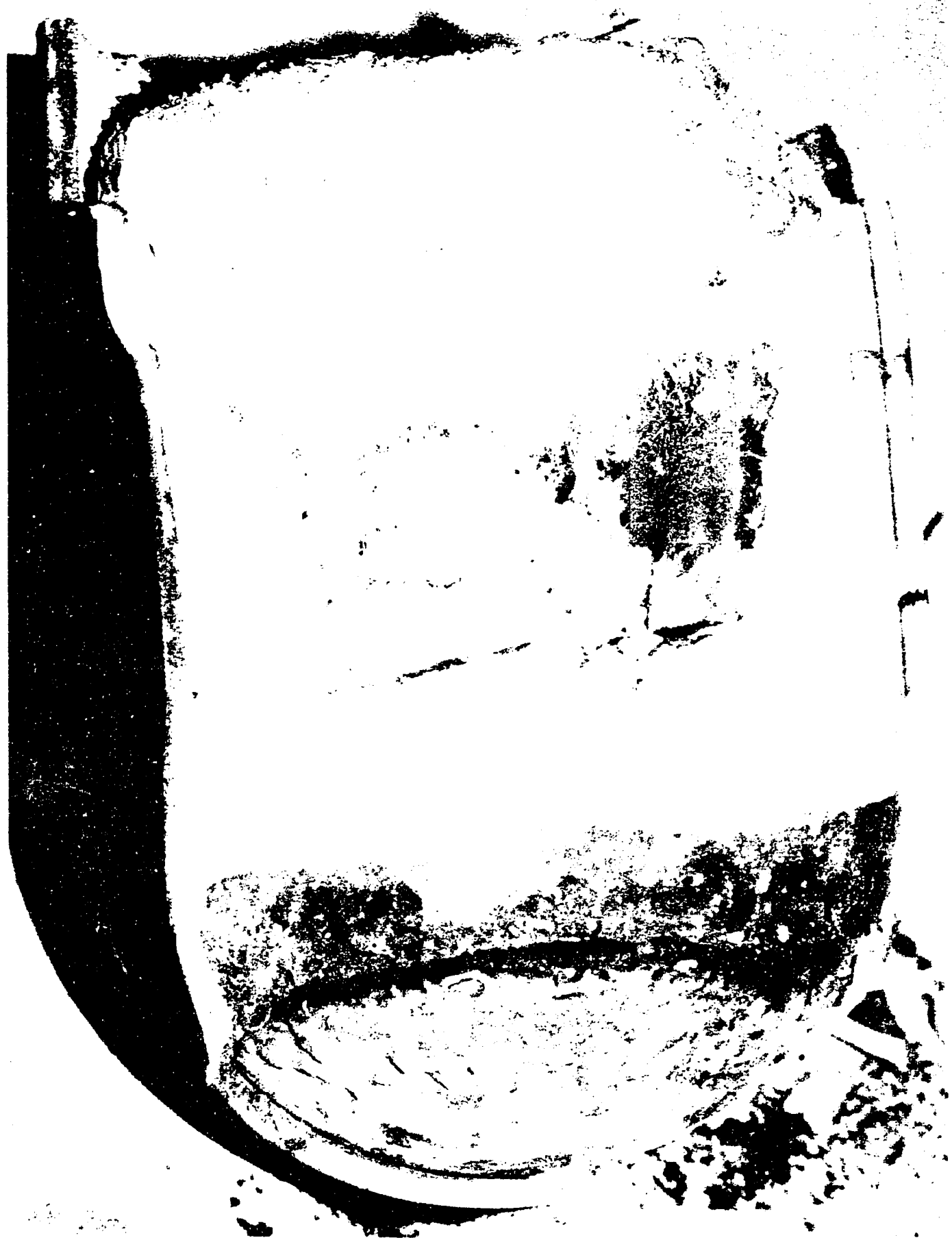

Fig. 22. Products from Run 5: magnesium layer on top, white and gray salt layers, and uranium alloy button on bottom. 

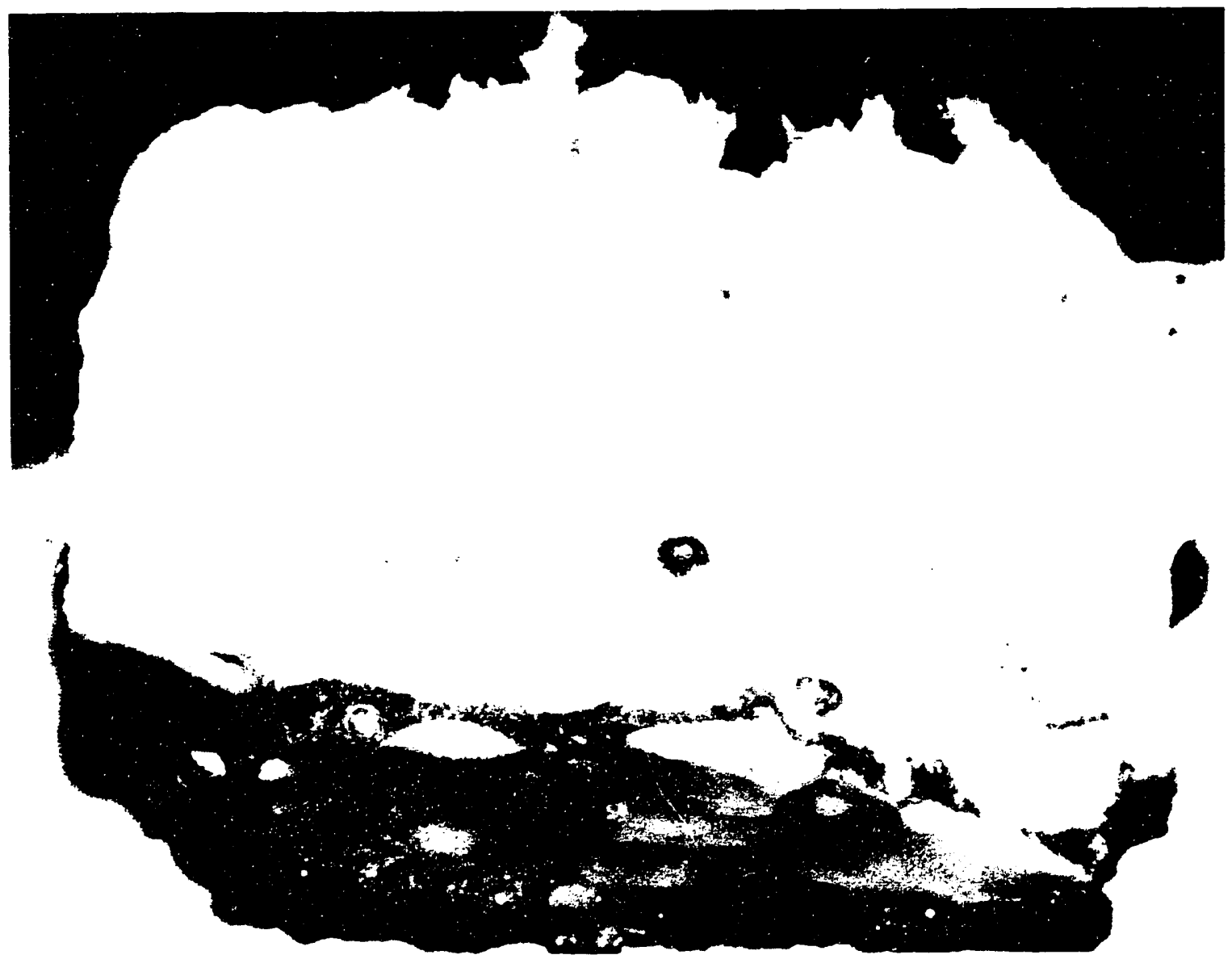

Fig. 23. Cross section of the gray, impure salt layer at the bottom showing some droplets of metal and thin layers of impurities. The gray color is apparently caused by small amounts of uranium or $\mathrm{UO}_{2}$

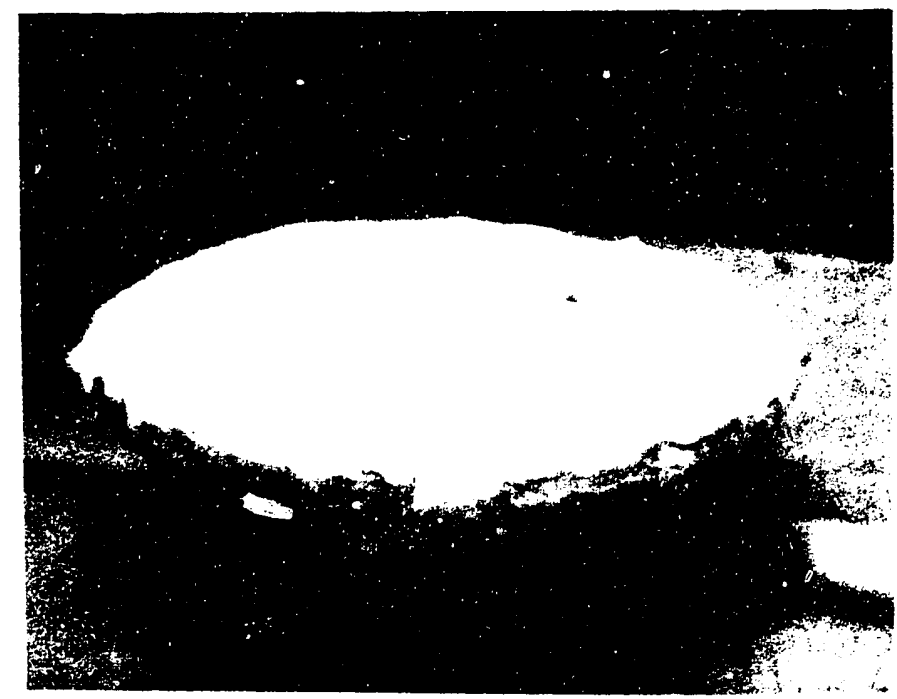

F. 24. Uranium alloy button from Run 5. 


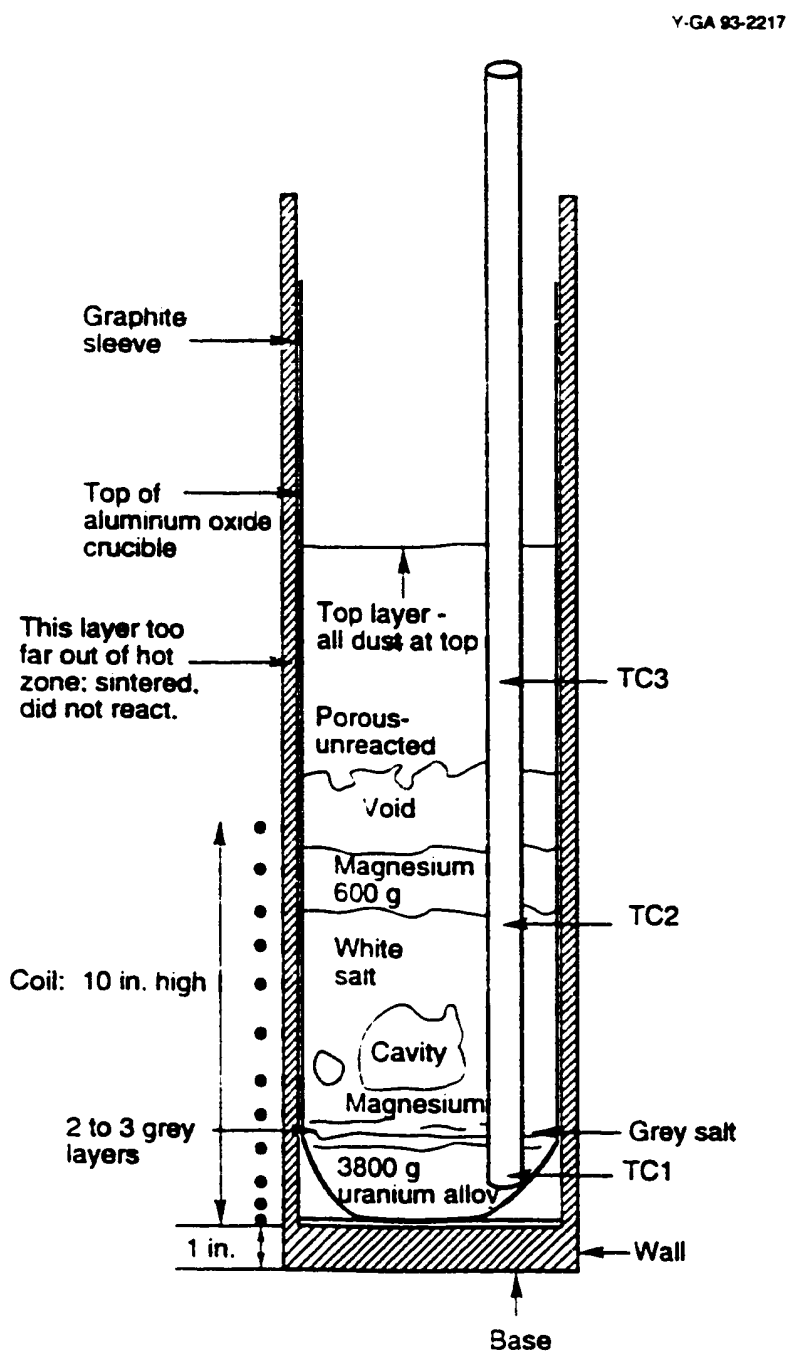

Fig. 25. Scale drawing of the reactor setup and products formed in Run 5. 


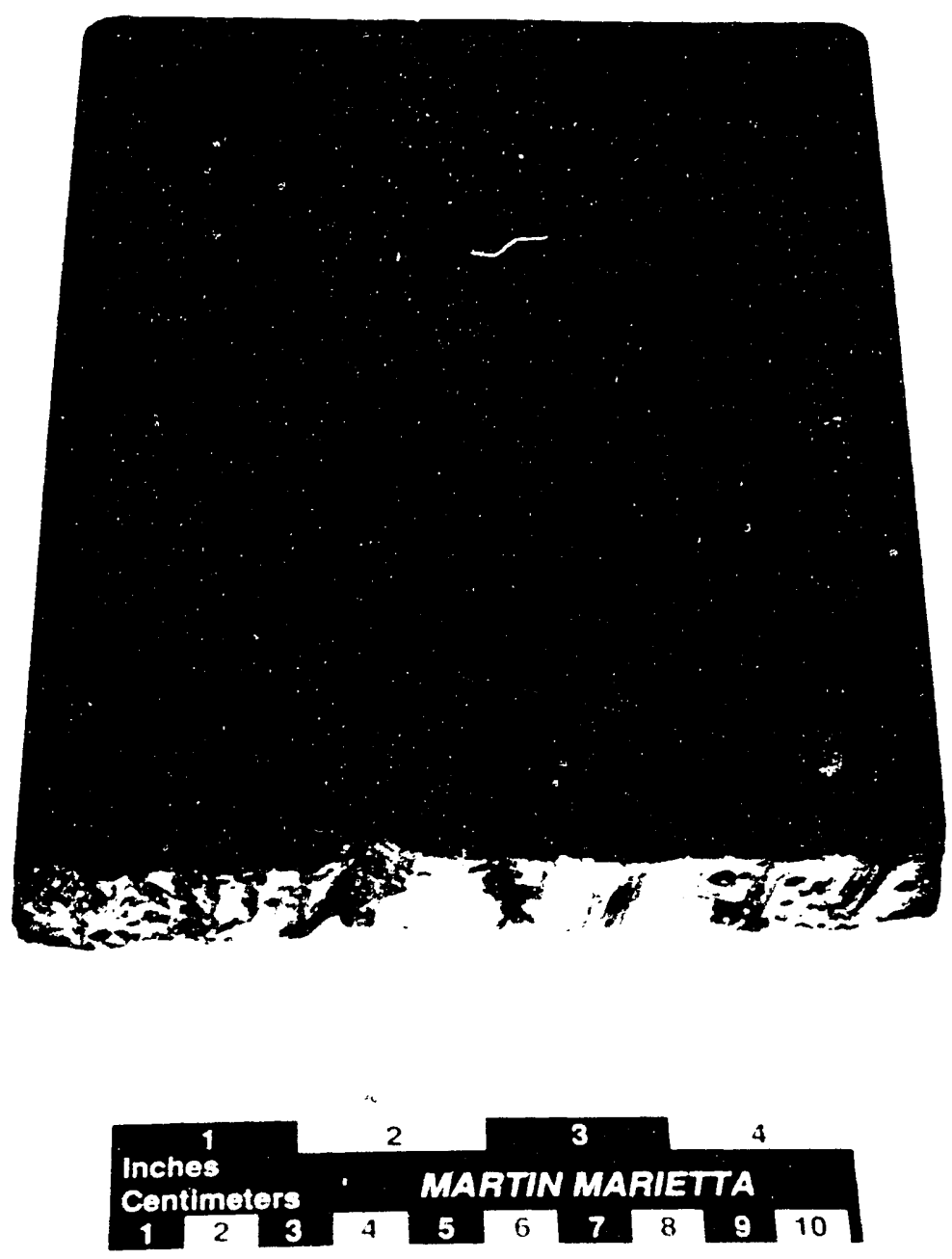

Fig. 26. Casting 1 with hot top removed. 


$$
1
$$




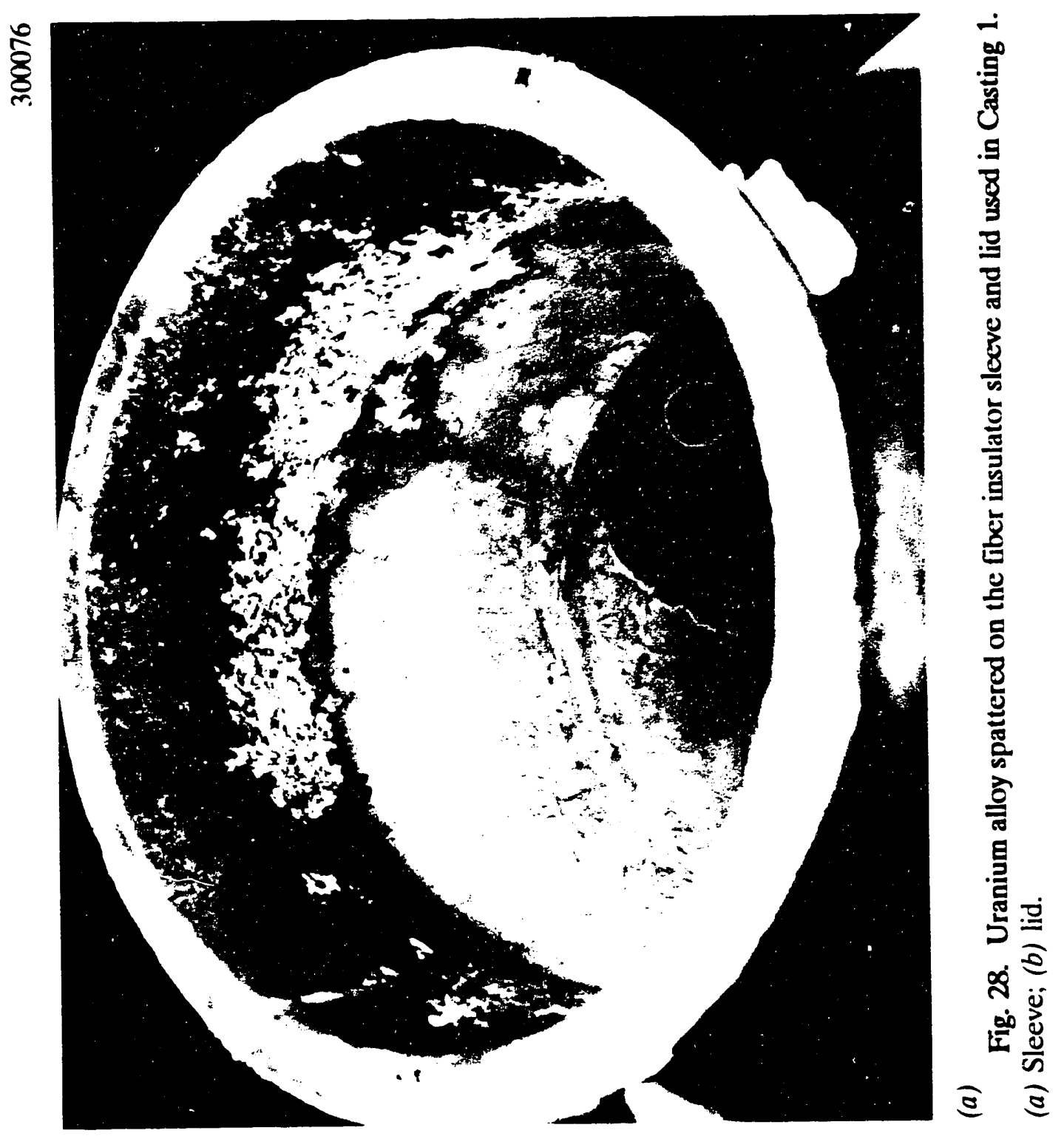




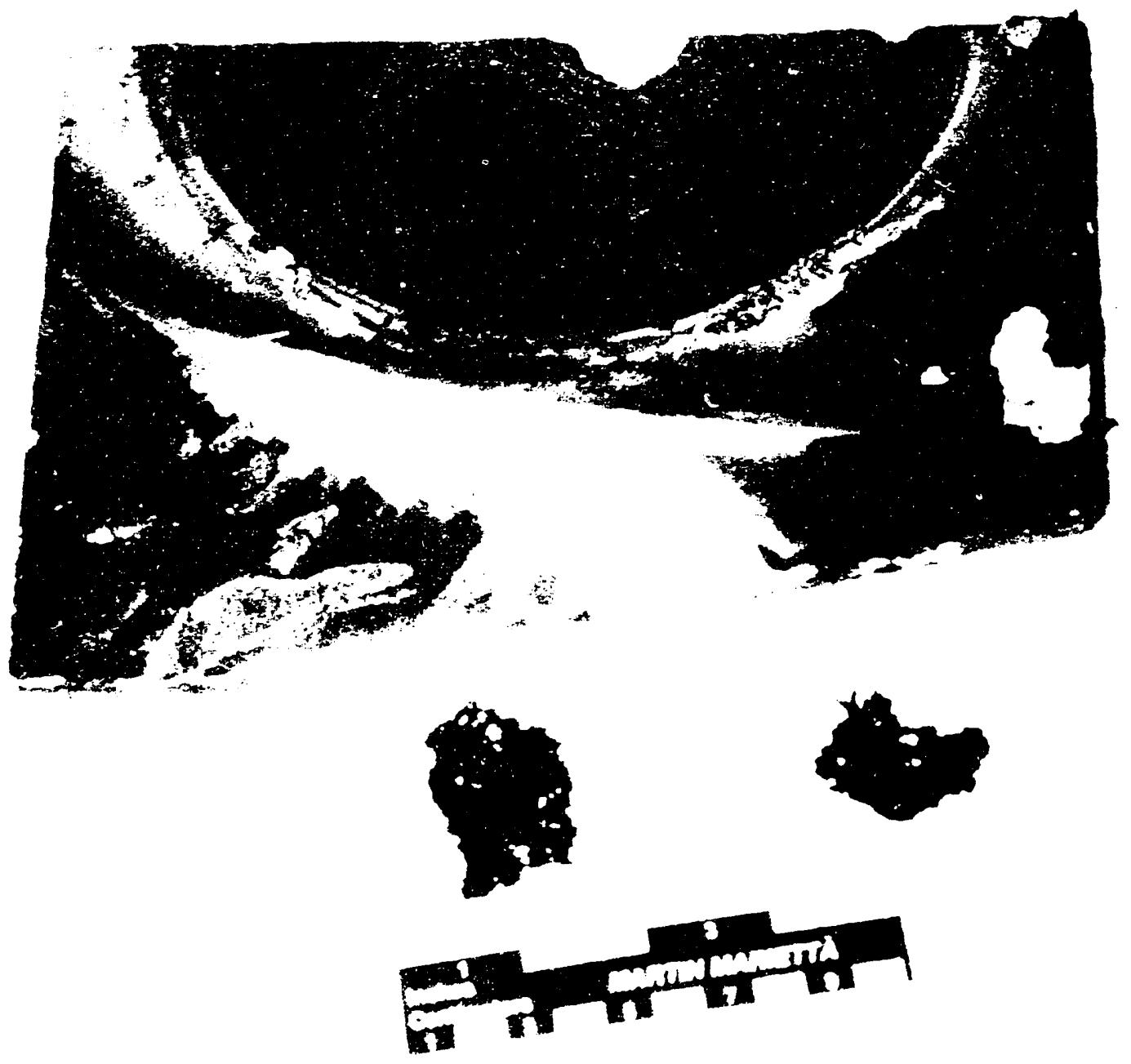

(h)

Fig. 28. Continued.

latk 4 Average concrntratsons of uranium, arin, and magnesium in the uranum allin acatiod in Runs 3 and 4

\begin{tabular}{|c|c|c|c|}
\hline & $\begin{array}{l}: ; i, \ldots: n \\
n !\end{array}$ & $\begin{array}{l}\text { is : } \\
\text { at: }\end{array}$ & 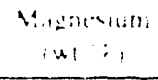 \\
\hline rint: & $m+2$ & ; & $13113=$ \\
\hline 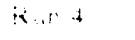 & $"$ & 2 & $\| \ln \mid$ \\
\hline 1 s.ting : & & $i: 1$ & $1111: 11$ \\
\hline
\end{tabular}


Various impurities in the uranium alloy from Run 3 are listed in Table 5. The presence of elements such as chromium and nickel is probably due to the uranium slowly eroding the stainless steel crust breaker/stirrer. The aluminum and silicon probably come from pieces of the alumina insulation falling down into the vessel.

\begin{tabular}{cc}
$\begin{array}{c}\text { Table S. Seloctod impurities and their } \\
\text { levets found in the uranium alloy } \\
\text { from Run }\end{array}$ \\
\hline & Level \\
Element & (ppm) \\
\hline $\mathrm{Al}$ & 200 \\
$\mathrm{C}$ & 137 \\
$\mathrm{Cr}$ & 100 \\
$\mathrm{Mn}$ & 150 \\
$\mathrm{Na}$ & 50 \\
$\mathrm{Ni}$ & 200 \\
$\mathrm{Si}$ & 125 \\
\hline
\end{tabular}

The gray layer of salt sometimes seen interfacing with the uranium (see Fig. 22) is of some concern. X.-ray diffraction of material from Run 4 has shown that this layer consists primarily of $\mathrm{NaCl}$ and $\mathrm{UO}_{2}$ with a lesser amount of $\mathrm{MgF}_{2}$. X-ray diffraction revealed that the material from Run 5 consists of $\mathrm{NaCl}$ with an intermediate amount of $\mathrm{MgF}_{2}$ and possibly small amounts of $\mathrm{MgO}$ and some other unidentified compounds. Electron microscopy of the same sample from Run 5 showed tiny specks of uranium or a uranium compound in the salt. Tiny uranium particles moving through the salt and causing discoloration are not a problem; however, if this gray layer is formed by the accumulation of uranium oxides, in time they will build up to a point at which they will clog the system. Uranium oxides could either be present as an impurity in the $\mathrm{UF}_{4}$ or be formed by the reaction of uranium metal with the alumina reaction chamber. One goal of future runs will be to monitor this layer to see if it grows as more material is run through the system. 


\section{FUTURE WORK}

For the next series of runs, a larger coil will be used for the induction furnace. This larger coil will allow us to simulate production runs by leaving room around the reactor for withdrawing the uranium alloy product. When the details of simultaneous metal and salt removal have been ironed out, a quasi-continuous run urill be made using two induction coils in the furnace. 


\section{Distribution}

Lawrence Livermore National Laboratory

D. H. Andrews

H. L. Chen

J. W. Dubrin

J. G. Harri

J. A. Horton

R. R. Miller

$\underline{\text { K-25 Plant }}$

R. L. Beatty (5)

S. Clinton

P. G. Schneider (2)

Oak Ridge National Laboratory

H. W. Hayden

Oak Ridge Y-12 Plant
A. L. DeMint
A. K. Lee/DOE-OSTI (2)
A. W. Maxey
W. G. Northcutt, Jr./E. L. Bird
9202 File Point
Y-12 Central Files - RC 

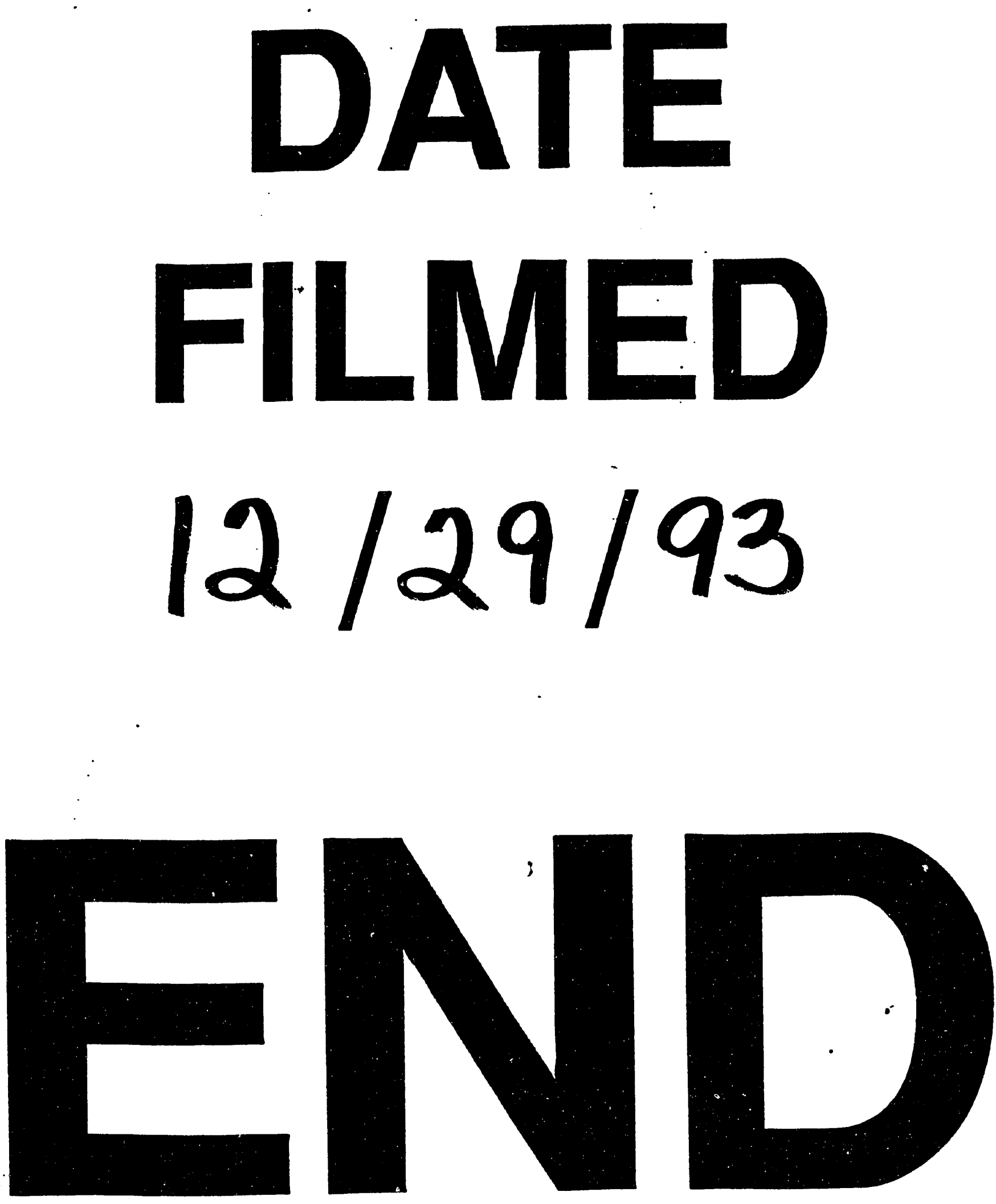
